\title{
NUEVAS INVESTIGACIONES ARQUEOLÓGICAS SUBACUÁTICAS EN EL ÁREA DE LA CALETA (CÁDIZ, ESPAÑA). ESTUDIO DE LAS EVIDENCIAS DE ÉPOCA PÚNICA (SIGLOS VI-III A.C)
}

\author{
RECENT UNDERWATER ARCHAEOLOGICAL RESEARCH AT LA CALETA (CADIZ BAY, SPAIN). \\ AN UPDATE ON PUNIC EVIDENCE $\left(6^{\mathrm{TH}}-3^{\mathrm{RD}}\right.$ CENTURIES BC)
}

\author{
ANTONIO M. SÁEZ ROMERO
}

Universidad de Sevilla

\author{
AURORA HIGUERAS-MILENA CASTELLANO \\ Centro de Arqueología Subacuática (IAPH)
}

\begin{abstract}
Resumen
La zona costera de La Caleta, en el extremo noroccidental de la isla de Cádiz, constituye desde los inicios de la investigación subacuática en la bahía gaditana uno de los principales escenarios de investigación a partir tanto de destacados hallazgos puntuales como de actuaciones geo-arqueológicas científicas. La interpretación de este conjunto de datos ha sido muy dispar, tanto como el grado de publicación de las campañas arqueológicas realizadas, y la información disponible se encuentra actualmente muy dispersa. Asimismo, algunas cuestiones como la aparición de materiales que han sido tradicionalmente considerados como evidencias cultuales (anforillas, quemaperfumes, terracotas, etc.) y su relación con los templos citados en las fuentes literarias clásicas han focalizado hasta ahora la mayor parte de estudios, dejando en segundo plano temas de gran importancia histórica. Se propone en estas páginas una revisión panorámica de la documentación generada por hallazgos casuales y campañas precedentes, conjugando estas evidencias con las proporcionadas por actuaciones sistemáticas desarrolladas recientemente (2008-2010), atendiendo especialmente a los restos materiales relativos a la etapa púnica (siglos VI-III a.C.). Adicionalmente, se plantearán algunas nuevas propuestas de interpretación de La Caleta en este periodo, acerca de su configuración geo-arqueológica y su relación con actividades portuarias, comerciales, cultuales o funerarias prerromanas.
\end{abstract}

Palabras clave. La Caleta, ánforas, púnicos, comercio marítimo, Gadir, prospección geofísica.

\begin{abstract}
The coastal area of La Caleta, which is located in the northwestern side of the current island of Cádiz, is a major landmark for underwater archaeological research in the Atlantic coastline of the Iberian Peninsula. During the last decades, it has provided important discoveries both from geo-archaeological campaigns and from non-scientific activities. The historical interpretation of this set of findings has been diverse, as much as it has been the publication of the results of the archaeological surveys, so the information about the site remains disperse and blurred nowadays. Also, key issues like the discovery of items identified as part of cultic ceremonies (such as miniature amphorae, perfume-burners or tymiatheria, terracottas, etc.), and the vicinity of some of the pre-Roman sanctuaries mentioned in classical literary sources, have focused most of the efforts on the study of the site, leaving a secondary role for other crucial topics. This paper discusses briefly the previous research and finds, and provides a panoramic picture of the results of recent archaeological surveys developed between 2008 and 2010. The study of the discoveries dating from the Punic period (6th - 3rd centuries BC) will be our main purpose, but new hypothesis about the geo-archaeological evolution of La Caleta and its surroundings and their role as port and cultic areas will be also discussed.
\end{abstract}

Key words. La Caleta, amphorae, punic, maritime trade, Gadir, geophysical survey.

Para citar este artículo / To cite this article: Sáez Romero A. M. y Higueras-Milena Castellano A. (2016). Nuevas investigaciones arqueológicas subacuáticas en el área de La Caleta (Cádiz, España). Estudio de las evidencias de época púnica (siglos VI-III a.C). Lucentum, XXXV, 9-41. doi: 10.14198/LVCENTVM2016.35.01

Para enlazar con este artículo / To link to this article:

http://dx.doi.org/10.14198/LVCENTVM2016.35.01 


\title{
NUEVAS INVESTIGACIONES ARQUEOLÓGICAS SUBACUÁTICAS EN EL ÁREA DE LA CALETA (CÁDIZ, ESPAÑA). ESTUDIO DE LAS EVIDENCIAS DE ÉPOCA PÚNICA (SIGLOS VI-III A.C)
}

\author{
RECENT UNDERWATER ARCHAEOLOGICAL RESEARCH AT LA CALETA (CADIZ BAY, SPAIN). \\ AN UPDATE ON PUNIC EVIDENCE $\left(6^{\mathrm{TH}}-3^{\mathrm{RD}}\right.$ CENTURIES BC)
}

ANTONIO M. SÁEZ ROMERO

Universidad de Sevilla

\author{
AURORA HIGUERAS-MILENA CASTELLANO \\ Centro de Arqueología Subacuática (IAPH)
}

\section{INTRODUCCIÓN}

Gadir, cuya fundación han situado algunas referencias literarias y la tradición historiográfica en los inicios de la expansión fenicia hacia el Occidente mediterráneo, fue uno de los principales puntos de asentamiento de los colonos orientales en su proceso de establecimiento en las puertas del Océano Atlántico. Las sucesivas investigaciones histórico-arqueológicas desarrolladas en la Bahía de Cádiz en el tramo final del siglo XX y en los últimos años hacen posible ahora no sólo corroborar esa importancia de la presencia fenicia en su entorno insular (desde la propia Cádiz hasta el entorno de Sancti Petri) y en la desembocadura de sus principales ríos (Castillo de Doña Blanca y Cerro del Castillo de Chiclana) sino que han permitido subrayar la importancia desde sus orígenes de su vinculación al medio marino y a la explotación de sus recursos como uno de los leitmotiv característicos de su configuración física y de su dimensión económica (Botto, 2014; Niveau, 2014; Sáez Romero, 2014a).

No cabe duda, a la luz de los testimonios arqueológicos y las fuentes literarias clásicas disponibles de que el conglomerado urbano de la bahía estuvo desde sus inicios en época arcaica íntimamente ligado al mar, a la navegación, a la pesca, a la extracción de sal y al comercio ultramarino, y que dicha relación fue fortaleciéndose y creciendo hasta alcanzar un punto culminante en la etapa romana tardorrepublicana de la familia Balbo e inicios de la fase altoimperial. Durante la etapa púnica, entre los siglos VI-III a.C. la bahía experimentó un enorme crecimiento poblacional y económico, alcanzando especialmente durante el siglo $\mathrm{V}$ a.C. sus conservas de pescado fama internacional, llegando a crear una considerable demanda de los mismos en Grecia como ha quedado testimoniado tanto por fuentes literarias como arqueológicas. A pesar de ello, es escasa la información que poseemos acerca de las infraestructuras portuarias, los arsenales o astilleros y las flotas de todo porte que debieron actuar como ingredientes fundamentales de este entramado urbano y económico orientado al mar, en el cual el comercio a través de las autopistas marítimas atlántico-mediterráneas fue uno de los ejes básicos durante todo el I milenio a.C.

La Caleta ha sido desde hace varias décadas uno de los principales escenarios del entorno subacuático de la isla gaditana suministradores de datos sobre la dinámica de evolución geomorfológica y de utilización del medio marino en relación tanto a la fase feniciopúnica del asentamiento como a la posterior ciudad romana de Gades. La conjunción durante la última centuria de hallazgos puntuales, donaciones de materiales, campañas de prospección y estudios de algunos de los conjuntos cerámicos recuperados hacen que se configure actualmente como la principal referencia historiográfica de la arqueología subacuática de la bahía para la Antigüedad, a pesar de tratarse de un entorno aún escasamente explorado de forma sistemática y con metodologías científicas modernas. Sin embargo, continúan abiertas y en plena discusión aún muchas de las incógnitas histórico-arqueológicas que se relacionan con este punto clave para entender el asentamiento gadirita, incluso en lo referido a las más significativas piezas halladas en aguas de La Caleta.

Se muestra por ello fundamental reactivar la dinámica de publicación de las actividades recientes llevadas a cabo en la zona y tratar de ligar esta nueva información con la aportada por las actuaciones anteriores y las principales propuestas y conclusiones obtenidas hasta la fecha. Esta mirada renovada a los hallazgos precedentes se muestra imprescindible para actualizar enfoques, atribuciones y cronologías a los materiales, tras varias décadas de sensible mejoría en el conocimiento de los repertorios materiales fabricados y consumidos en los yacimientos terrestres de la bahía y de la región. Este será el único medio de superar el estado de la cuestión actuar y desembocar en el planteamiento de nuevas actuaciones que contribuyan al avance del conocimiento de este lugar clave para 
leer la secuencia histórica de la bahía gaditana. El paralelo crecimiento cuantitativo y cualitativo acerca del poblamiento fenicio-púnico de este rincón del antiguo archipiélago gadirita y de sus características paleotopográficas termina de dibujar un escenario propicio para la discusión de nuevos materiales y el planteamiento de nuevas hipótesis de interpretación.

Así, el propósito principal de estas páginas será el intentar aportar nuevos mimbres al debate en base al análisis de los resultados de actuaciones muy recientes desarrolladas entre 2008 y 2010 , que conllevaron tanto la aplicación de nuevas técnicas de rastreo y lectura de los fondos marinos como la documentación detallada y sistemática de nuevos materiales mediante prospecciones. Concretamente, a través del estudio de los materiales de época púnica (datados entre los siglos VI y III a.C.) se realizará una valoración crítica de la historiografía del yacimiento, es decir, de las evidencias conocidas precedentemente y de las hipótesis sobre la funcionalidad del entorno, revisándose el origen de los materiales, la posible existencia de pecios o zonas de fondeadero, la cronología de algunos de los grupos cerámicos más característicos y la evolución de la línea costera en este sector insular. En suma, una valoración de base arqueológica sobre la dinámica de uso de uno de los puntos clave del diálogo fluido establecido entre Gadir y el océano en el tercio central del I milenio a.C., en una de las etapas más prósperas y de mayor proyección internacional de la bahía en el plano económico-comercial.

\section{LA INVESTIGACIÓN ARQUEOLÓGICA EN EL ENTORNO DE LA CALETA}

La zona objeto de estudio en estas páginas se encuentra en el extremo noroccidental de las islas gaditanas que configuraron el archipiélago de las Gadeira, identificándose en concreto como una zona caracterizada por un brazo de mar enmarcado por las lenguas de arrecifes de Santa Catalina-Punta del Nao y San Sebastián en el frente occidental de lo que debió ser la islita de Erytheia, donde según señala Estrabón (III.5.3) se ubicó el oppidum primigenio del asentamiento fenicio gadirita. Se trata de una franja que debió caracterizarse por un continuo paso de embarcaciones de todo tipo, la existencia de fondeaderos y la inevitable presencia de múltiples naufragios, la cual ha deparado abundantes restos bajo sus aguas en las últimas décadas incluyendo una gran variedad tipológica de yacimientos arqueológicos propiamente subacuáticos (sin olvidar elementos vinculados a la erosión marina). Algunos de ellos como el conocido capitel protoeólico documentado en las inmediaciones del brazo de San Sebastián quizá asociado al santuario gaditano o el «timiaterio» documentado en la Punta del Nao vinculado al santuario de Astarté, enfatizan esta relación con el medio marino y también el carácter de área portuaria con una fuerte carga sacra en ambos lados (norte y sur) de este canal Bahía-Caleta (Pérez López, 1998; Belén, 2000; Ferrer, 2002; Marín, 2010; Maya et alii, 2014).

La riqueza de los fondos marinos de La Caleta ha quedado demostrada por la cantidad y entidad de los hallazgos, una elevada diversidad de objetos y restos de diferente cronología, origen y estado de conservación que se encuentran ocultos por la mala visibilidad que provocan los fangos característicos de la zona. Estas dificultades de accesibilidad han provocado que la zona haya sido escasamente explorada por parte de la investigación científica más reciente, pero sí se ha visto sometida a un fuerte deterioro por acción erosiva y sobre todo antrópica debido a la cercanía de la costa y la inmediatez a la propia ciudad de Cádiz, con la consiguiente pérdida de datos y la dispersión de los objetos en colecciones privadas o donaciones a instituciones. Hay que indicar además que se trata de una zona difícil en cuanto a la dinámica marina, que ha podido en muchos casos dispersar restos arqueológicos por los fondos haciendo difícil la interpretación actual de los mismos.

La paleogeografía de las islas gaditanas a través de las fuentes historiográficas y los últimos estudios geomorfológicos constituye uno de los escenarios de dialéctica científica más activos y que más datos han aportado para ubicar en contexto los diversos hallazgos arqueológicos documentados a lo largo de las últimas décadas. La evolución paleotopográfica de las costas de la bahía en general, y de este sector norte de la isla gaditana en particular, han provocado ríos de tinta desde hace más de una centuria, sin que hasta el momento se haya llegado a un punto de total consenso ni se pueda considerar ni mucho menos cerrada la investigación geoarqueológica de la zona. Más bien al contrario, en los últimos años la aplicación de nuevas técnicas y novedosos enfoques ha permitido superar en clave interdisciplinar las hipótesis iniciales que se centraban en la dualidad erosión (oceánica) y sedimentación (ríos del interior de la bahía), para ofrecer una imagen mucho más detallada y compleja de sectores concretos de este dinámico estuario.

Los ensayos de reconstitución de la zona ha zona han sido cuantiosos combinando no menos diversos ingredientes científicos, algo imprescindible considerando que el entorno costero gaditano que se ha visto transformado profundamente por diversos agentes naturales (variaciones del nivel del mar, erosión, sedimentación, etc.) y antrópicos (dragados, deforestación, canteras, infraestructuras costeras, etc.), presentando por ello grandes dificultades a la hora de reconstruir el paisaje antiguo. A estos cambios, se han unido no menos numerosos y discutidos intentos de interpretación de la evolución del litoral y del paleo-archipiélago a partir de las descripciones aportadas por las fuentes clásicas, en su mayor parte mucho más tardías a la fase histórica que interesa en estas páginas y por tanto complejas de interpretar dado el décalage temporal que las separa de la fase fenicia y de las realidades 
descritas (Corzo, 1980; Álvarez, 1992). Desde esta perspectiva filológica se han hecho no pocos intentos de hacer coincidir las referencias clásicas con el paisaje actual, centrándose en la ubicación de la fundación fenicia o de los principales hitos de la Gades de Balbo, en concordar el número y tamaño de las antiguas islas, así como la localización de los templos principales (y, en particular, del dedicado a Melqart/Hercules Gaditanus; Corzo, 1992).

Los cambios que han moldeando la costa de la bahía, en la que se suceden marismas, playas, ensenadas, acantilados y bajos rocosos, pueden relacionarse principalmente con transformaciones geotectónicas (fallas), cambios morfogenéticos (operados en las condiciones climáticas, las oscilaciones eustáticas, los procesos activos de erosión y sedimentación, etc.), así como la muy diversa composición geomorfológica de la bahía gaditana. En el caso concreto de la ciudad de Cádiz, el tramo litoral situado al noroeste de su casco urbano se caracteriza por la abundancia de materiales rocosos, restos de relieves terciarios formados a finales del Plioceno y comienzos del Cuaternario (Gracia et alii, 2012), en forma de conglomerados cementados con ostras y pectínidos conocidos popularmente como «roca ostionera», que aparecen junto con materiales margosos y arenosos (Domínguez-Bella, 2008). Esta base geológica la encontramos al descubierto al noroeste de la actual ciudad, en el paisaje de La Caleta, formada por un brazo de mar enmarcado por dos arrecifes compuestos de «piedra ostionera», San Sebastián (Punta del Sur) y Santa Catalina (Punta del Nao), extremos más occidentales de dos de las antiguas islas, que el mar sigue moldeando y erosionando actualmente y que han sido objeto de fuertes transformaciones antrópicas (canteras) en los últimos siglos.

Puede considerarse por tanto que el caso de $\mathrm{LaCa}$ leta ocupa un puesto primordial en el conjunto de esta historiografía previa sobre la evolución geomorfológica de las costas de la bahía y de la interacción de estos cambios con los modelos de ocupación y explotación antrópica del territorio. Así, las primeras investigaciones de Ponce (1985) sobre la existencia de un canal enmarcado por los brazos rocosos de Santa Catalina y San Sebastián que comunicaba con la bahía pueden ser considerados la base de la investigación más reciente, que ha perfilado en los últimos años la morfometría del canal, su proceso de cegamiento y el debate sobre el archipiélago gaditano descrito sucintamente por las fuentes literarias clásicas (Corzo, 1980; Ramírez, 1982). Sobre todo en las dos últimas décadas la investigación interdisciplinar de carácter geoarqueológico ha cobrado aún mayor auge en el marco general de la bahía, recibiendo este sector una atención notable debido a su relación con el canal portuario principal del asentamiento (un estado de la cuestión en Arteaga y Schulz, 2008 y Alonso et alii, 2009).

Centrándonos en el paisaje correspondiente a los dos primeros tercios del I milenio a.C. para este sector noroeste del frente marítimo de la actual isla gaditana, cabe señalar que la acción de la erosión oceánica (principalmente, pero también en unión a otros factores) ha transformado enormemente la línea costera, convirtiendo en bajos rocosos mareales las dos lenguas de tierra que se extendían hacia el ocaso enmarcando el canal (Santa Catalina-Punta del Nao al norte y San Sebastián al sur). Del mismo modo, es posible que no solo el canal reuniese condiciones naturales suficientes para ser usado como fondeadero, puesto que al norte de Punta del Nao muchos de los actuales bajos (La Cepera, Chapitel, Laja Herrera, Los Cochinos, La Freidera, Canal del Sur, etc.) debieron constituir islotes de pequeño porte que habrían constituido una barrera que enmarcaría una zona de aguas resguardadas alrededor de Canal del Sur (Alonso et alii, 2009; Gracia et alii, 2012). Las características concretas de este sistema y su evolución a través del I milenio a.C. no pueden ser concretadas aún, pues deberán ser proyectos específicos de carácter geoarqueológico los que aporten nuevas evidencias al respecto.

El propio canal Bahía-Caleta constituye un eje de discusión aún plenamente abierto y dinámico, sin que se haya llegado a un consenso definitivo respecto a su trazado exacto y en torno al proceso de cegamiento parcial que parece que originó que en época romana la isla de Erytheia quedase conectada con el extremo norte de la Kotinoussa. Si para unos autores este canal era completamente transitable en época fenicia arcaica (Gener et alii, 2014), para otros parece que su cegamiento parcial comenzó ya durante el I milenio a.C., con aportes de arenas de tipo eólico y sedimentos limosos propios de la bahía que habrían creado un «puente» entre las dos islas en las inmediaciones de la actual playa de La Caleta y el barrio de La Viña (Arteaga et alii, 2008). En relación a este debate la arqueología preventiva terrestre y la revisión de otras fuentes históricas han aportado sugerentes novedades en fechas recientes, como la constatación de la existencia de una posible zona pantanosa en la zona trasera del castillo de Santa Catalina y sus inmediaciones posiblemente debida a los aportes del conocido como «Arroyo de la Zanja», un canal de arroyada que proveniente de la zona alta de la Erytheia parece desembocaba en esta zona y cuyos aportes podrían haber contribuido decisivamente a la colmatación parcial del canal Bahía-Caleta (Sáez y Belizón, 2014; Pajuelo et alii, e.p.).

Este entorno singular debió ser sin duda una de las razones que motivó el establecimiento de la colonia en época fenicia y de su indisoluble relación con el mar, además de contribuir decisivamente al progreso de su economía marítima. Además de funciones portuarias, estos brazos insulares de Santa Catalina y San Sebastián parece que contaron con un carácter sacro desde momentos tempranos de la presencia fenicia, tal y como sugieren las recientes excavaciones efectuadas en San Sebastián (Maya et alii, 2014, testimoniando una ocupación desde el siglo VII a.C. que los autores 
vinculan al santuario de Kronos citado por las fuentes literarias romanas). En todo caso, la inexistencia de testimonios edilicios de infraestructuras portuarias fenicio-púnicas y el escaso conocimiento que aún tenemos de estas áreas sacras vinculadas a Kronos/Baal Hammon y Astarté/Venus ${ }^{1}$, hace que debamos ser cautos respecto a las características concretas del paisaje sagrado vinculado a este reborde oceánico y a la transformación antrópica del mismo en la etapa prerromana (dado que no se puede descartar la realización de modificaciones de importancia destinadas a adecuar estos espacios, además de la construcción de edificios sacros, áreas funerarias ${ }^{2}$, etc.).

Las inmersiones vinculadas a la recuperación de material arqueológico comenzaron muy tempranamente en este entorno de La Caleta, y ya a inicios del siglo XX se tiene constancia del hallazgo de ánforas y otros objetos, algunos de ellos fotografiados entre 1908 y 1909 en el museo arqueológico (Romero de Torres, 1934). Sería sin embargo a partir de mediados de los cincuenta cuando la prospección por parte de buzos aficionados se intensificaría, siendo intensamente expoliados los yacimientos de este sector hasta dos décadas más tarde. Los primeros trabajos de investigación científica se iniciaron en los años setenta de la mano de Olga Vallespín, en varias localizaciones entre 1973-1978 y 1983-1984 (Vallespín, 1977; 1985). A inicios de los ochenta (1981-1983) otros proyectos paralelos bajo la dirección de Juan Ramón Ramírez Delgado desarrollaron también actividades de prospección en los bajos al noroeste de Cádiz, aportando interesantes datos materiales y nuevos enfoques acerca de la evolución paleogeográfica y la funcionalidad portuaria y sacra de la zona en la Antigüedad (Ramírez

1. Avieno (Ora Maritima 315) relataba que «del lado de la fortaleza donde muere el día hay una isla consagrada a Venus Marina, y en ella un templo con profunda cripta y un oráculo». Por su parte, Estrabón (Geografía, III.5.3) describe respecto a esta zona que «la ciudad yace en la parte occidental de la isla, y cerca de ella, en la extremidad que avanza hacia el islote, se alza el Kronion» (traducción de Juan Gavala y Laborde), lo que tradicionalmente se ha relacionado con su localización en el brazo del Castillo de San Sebastián.

2. Existen diversos testimonios de distinta relevancia sobre la presencia de áreas de enterramiento de época antigua en este sector erosionadas y probablemente borradas por efecto de la erosión. A este respecto es interesante citar la noticia transmitida por Fray Gerónimo de la Concepción (1690) sobre el estudio de una lápida funeraria romana que se recuperó en la mar inmediata al Castillo de San Sebastián hacia 1670. "Entre el islote de San Sebastián y la piedra llamada La Olla existe un sitio denominado el paso o canal del N.; hacia la citada piedra, según datos verídicos, existe una enorme cantidad de huesos humanos. Muchos creen son procedentes de náufragos que hayan perecido en dicho lugar. Creo más bien sepulturas de los romanos por haberse recogido de debajo del mar en el año 1670 una lápida sepulcral en la punta del islote de San Sebastián» (Vera y Vera, 1887, 48-49). y Mateos, 1985). Salvo la campaña de 1989 dirigida por Carlos Alonso Villalobos (Alonso, 1991), a partir de 1992 los trabajos han sido llevado a cabo de forma intermitente bajo la dirección del Centro de Arqueología Subacuática (IAPH) de la Junta de Andalucía, en el marco de tareas de catalogación y protección de estos yacimientos, que finalmente fueron objeto de inventario oficial y de nuevas publicaciones (Alzaga et alii, 1999, 122-129; Alonso et alii, 1999; 130-137; Rodríguez y Martí, 2001; Martí y Rodríguez, 2003, 399-416; Martí, 2010).

En lo referido a hallazgos arqueológicos relacionados con la fase prerromana del asentamiento hay que señalar que no son escasos los descubrimientos de diferente tipología y magnitud histórica que se han acumulado en las últimas décadas, fruto tanto de hallazgos casuales como de prospecciones científicas. Es especialmente relevante en este capítulo el entorno inmediato al canal de la Caleta, y sobre todo en la Punta del Nao y bajos aledaños, donde se han localizado numerosos ítems cerámicos de diversa tipología a los que se ha atribuido tradicionalmente un carácter cultual/votivo, caso del «timiaterio» trípode (Blanco, 1970; Jiménez, 2007), «ampollas» o dipper juglets (Pérez Hormaeche, 1993), ánforas de pequeño formato (García y Bellido, 1971; López y García, 1985; Muñoz, 1993), quemaperfumes de doble cazoleta (Pérez Hormaeche, 1990), terracotas de diversa tipología (Ramírez y Mateos, 1992 y 1994; Álvarez, 1997), discos cerámicos (Ramírez y Mateos, 1985). El lado meridional del canal de La Caleta ha sido menos pródigo en cuanto al número de hallazgos, pero entre ellos se encuentran piezas de singular interés, como el capitel protojónico documentado en el entorno de San Sebastián y que ha sido vinculado a una estructura cultual de cronología incierta (Pemán, 1959; Marín y Jiménez, 2011).

Las ánforas de transporte púnicas han sido documentadas en diversos puntos de este reborde marítimo, aunque hasta el momento han recibido una atención secundaria respecto de los objetos de tipología suntuaria, siendo escasos los estudios específicos publicados y aún menos las informaciones contextuales (Vallespín, 1985; Alonso et alii, 1991; Muñoz, 1993; Martí, 2010). Asimismo, es importante destacar la práctica ausencia de datos concretos sobre la existencia de naufragios de cronología prerromana en toda la zona, frente a la abundancia de materiales dispersos, siendo muy vagas y aún no contrastadas mediante sondeos las noticias sobre un posible pecio de los siglos $\mathrm{V}$ o IV a.C. situado en las cercanías de La Albujera, a la entrada del canal (denominado «Pecio de Juan Villa», por su descubridor) en una zona que los buceadores conocen como «La Escombrera», que se tapa y destapa según los vientos y las corrientes a lo largo del año, y donde sostienen la presencia de una significativa concentración de material anfórico de época púnica (T-11213 o T12110), aparentemente en buen estado de conservación. 


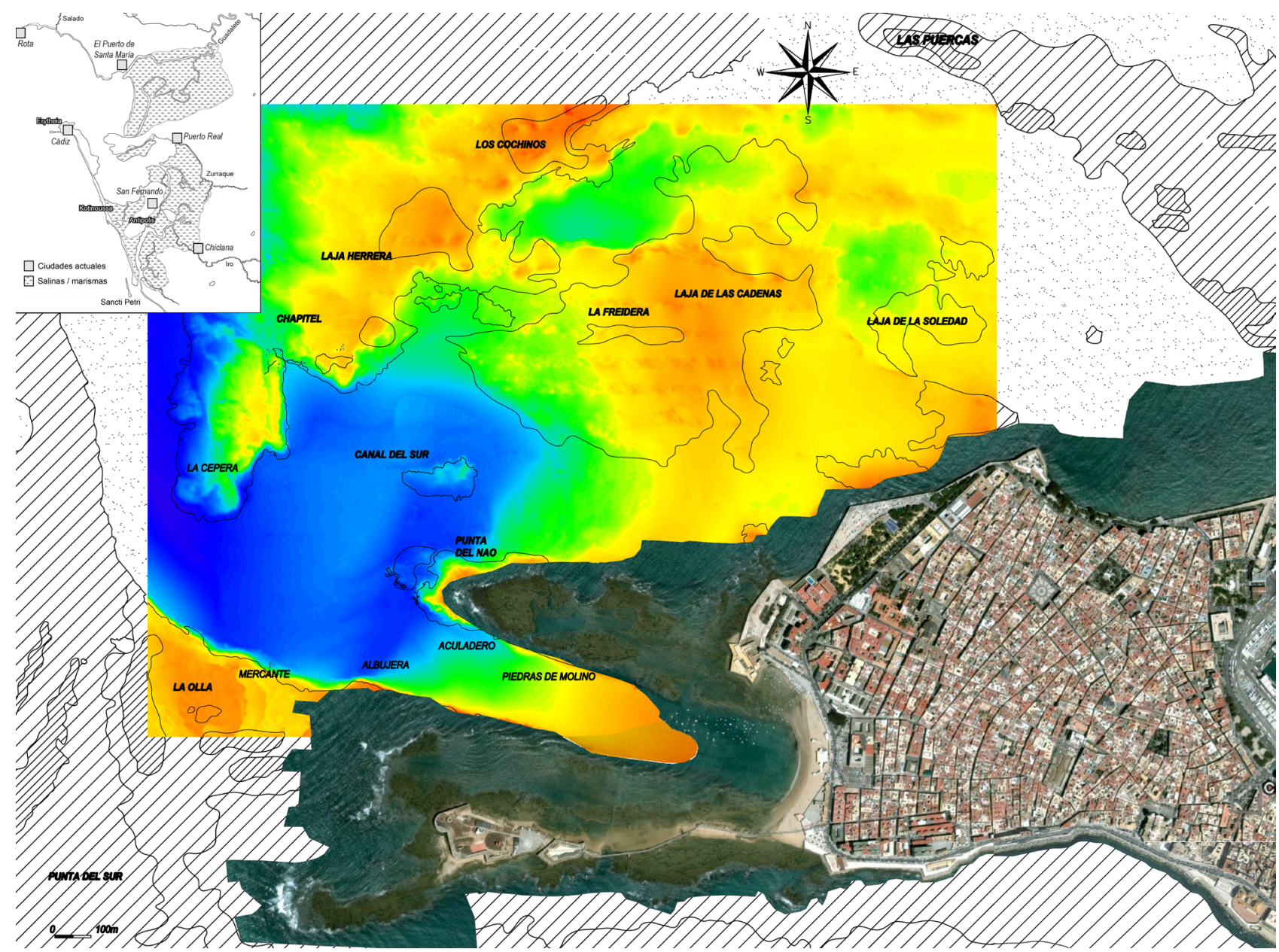

Figura 1: Plano general de la zona objeto de estudio en el contexto de la Bahía de Cádiz (recuadro) con indicación de los principales yacimientos de los que proceden los materiales estudiados y de los resultados de los estudios batimétricos efectuados con motivo del proyecto.

\subsection{Resultados De la ACTUACiÓN ARQUEOLÓGICA PUNTUAL (2008-2010)}

Los materiales estudiados en estas páginas proceden de las actividades de prospección y sondeo desarrolladas en el ámbito del proyecto «Aplicación experimental de técnicas geofísicas para la localización, investigación y difusión del Patrimonio Arqueológico en la zona de La Caleta (Cádiz)» (oficialmente una Actividad Arqueológica Puntual según el reglamento vigente de la Junta de Andalucía, con Ref. IDPH. Expte. 05/PU/CA/08, siendo autorizada con fecha 12 de Mayo de 2008 y quedando finalizada formalmente el 31 de julio de 2010). Este proyecto fue impulsado desde el Centro de Arqueología Subacuática (CASIAPH) como parte de una serie de actuaciones más amplias englobadas en el proyecto de «Carta Arqueológica Subacuática de Andalucía», siendo dirigido por A. Higueras-Milena Castellano con un amplio equipo técnico, y contando con algunos colaboradores externos para la realización de tareas determinadas (lo cual ha dado en este caso origen al presente estudio de materiales). El proyecto pretendía esencialmente, además de reactivar las investigaciones científicas en la zona, la elaboración de un mapa de distribución de objetos arqueológicos -superficiales y soterrados-del área de La Caleta incluyendo los restos materiales ya conocidos en la historiografía precedente y otros que se pudiesen detectar durante las propias prospecciones desarrolladas. Es decir, que además de desarrollar prospecciones geofísicas que permitiesen avanzar en el conocimiento de la geomorfología de los fondos de La Caleta y su entorno, uno de los objetivos básicos del proyecto ha sido el intentar contextualizar la información material disponible en relación al tránsito marítimo desde la Antigüedad hasta fechas recientes.

El área delimitada por el proyecto (Fig. 1) se encuentra incluida dentro de la Zona de Servidumbre Arqueológica denominada «Espacio subacuático Bahía de Cádiz» (catalogada en la Orden de 20 de abril de 2009, en BOJA n ${ }^{\circ} 101$ de fecha 28 de mayo de 2009), localizándose dentro de ella seis Zonas Arqueológicas (ZA) (Decreto 285/2009, de 23 de junio, en BOJA num. 129 de 6 de julio de 2009): El Aculadero, Punta del Nao, Piedras de Molino, Bajo de Chapitel, Cepo de Plomo y Punta del Sur. En ellas se localizan 

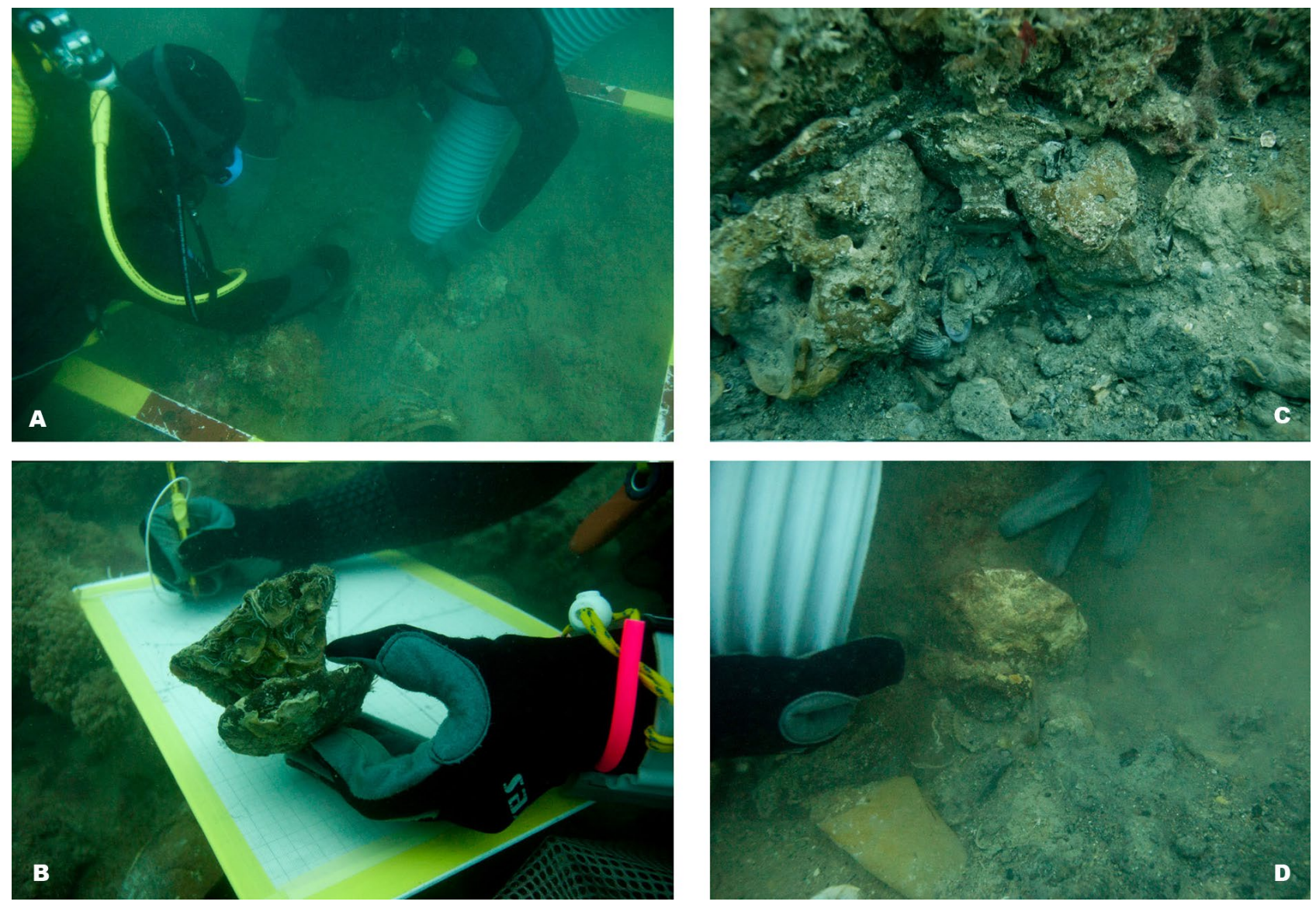

Figura 2: Perspectivas diversas de los trabajos llevados a cabo en los fondos subacuáticos de los yacimientos del área de La Caleta (Fotografías fondo IAPH, J.M. Higueras-Milena): excavación de uno de los sondeos de 1x1m (a); posicionamiento sobre plano de un pebetero cerámico durante la fase de prospección (b); detalle de cerámica púnica in situ (c) y proceso de excavación con manga de succión de uno de los pebeteros (d).

yacimientos desde época fenicio-púnica y romana hasta medieval, moderna y contemporánea, con una amplia tipología de los hallazgos y de sus cauces de documentación. Parte de la metodología y de los resultados obtenidos se han dado ya a conocer en forma de avance preliminar en el I Congreso Nacional de Arqueología Náutica y Subacuática celebrado en Cartagena en 2013 (Higueras-Milena y Saez, 2014), proporcionando una primera panorámica de los resultados geofísicos, de las características de los yacimientos (tipología y cronología) y de las inferencias histórico-arqueológicas obtenidas a partir del estudio de los materiales asociados a cada una de las seis áreas principales objeto de atención ${ }^{3}$.

3. Además se encuentran en curso de publicación varios trabajos más dedicados al análisis específico de los materiales de época fenicia arcaica (Sáez e Higueras-Milena, e.p.), a la fase romano-republicana (Higueras-Milena y Sáez, e.p.) $\mathrm{y}$ al estudio de algunas ánforas romanas fabricadas en talleres del Mediterráneo oriental en época imperial (González et alii, e.p.). También ha sido recientemente publicada una colección de material anfórico que incluye ejemplares desde época púnica hasta la fase romana imperial procedente de $\mathrm{La}$ Caleta y depositado en el Museo Histórico Municipal de San
A nivel metodológico general cabe insistir en que el proyecto ha analizado el comportamiento de las diversas técnicas geofísicas en una zona de gran diversidad en cuanto a los tipos de fondo (arena, cascajo, limos, rocas), profundidades y yacimientos (cerámicas, elementos metálicos, pétreos, óseos, etc.), valorando las respuestas que proporcionan estos sistemas (sonar de barrido lateral, magnetómetro marino ecosonda multihaz y perfilador sísmico), complementando la actuación con la prospección visual tradicional, obteniendo unos importantes resultados que amplían el conocimiento de la historia gaditana a partir de datos con una amplia diacronía (desde la Antigüedad hasta la etapa contemporánea). Asimismo, durante la ejecución del proyecto se planteó la intervención puntual en nuevas zonas de interés localizadas, ejecutándose sondeos arqueológicos en las áreas de La Cepera, Punta del Nao y Canal del Sur (en este último caso, en dos

Fernando (Sáez et alii, 2016a), y se encuentran en fase de preparación tanto la publicación de los materiales romanos y tardoantiguos de las prospecciones de 2008-2010 como otros conjuntos o piezas significativas procedentes de hallazgos puntuales o donaciones. 


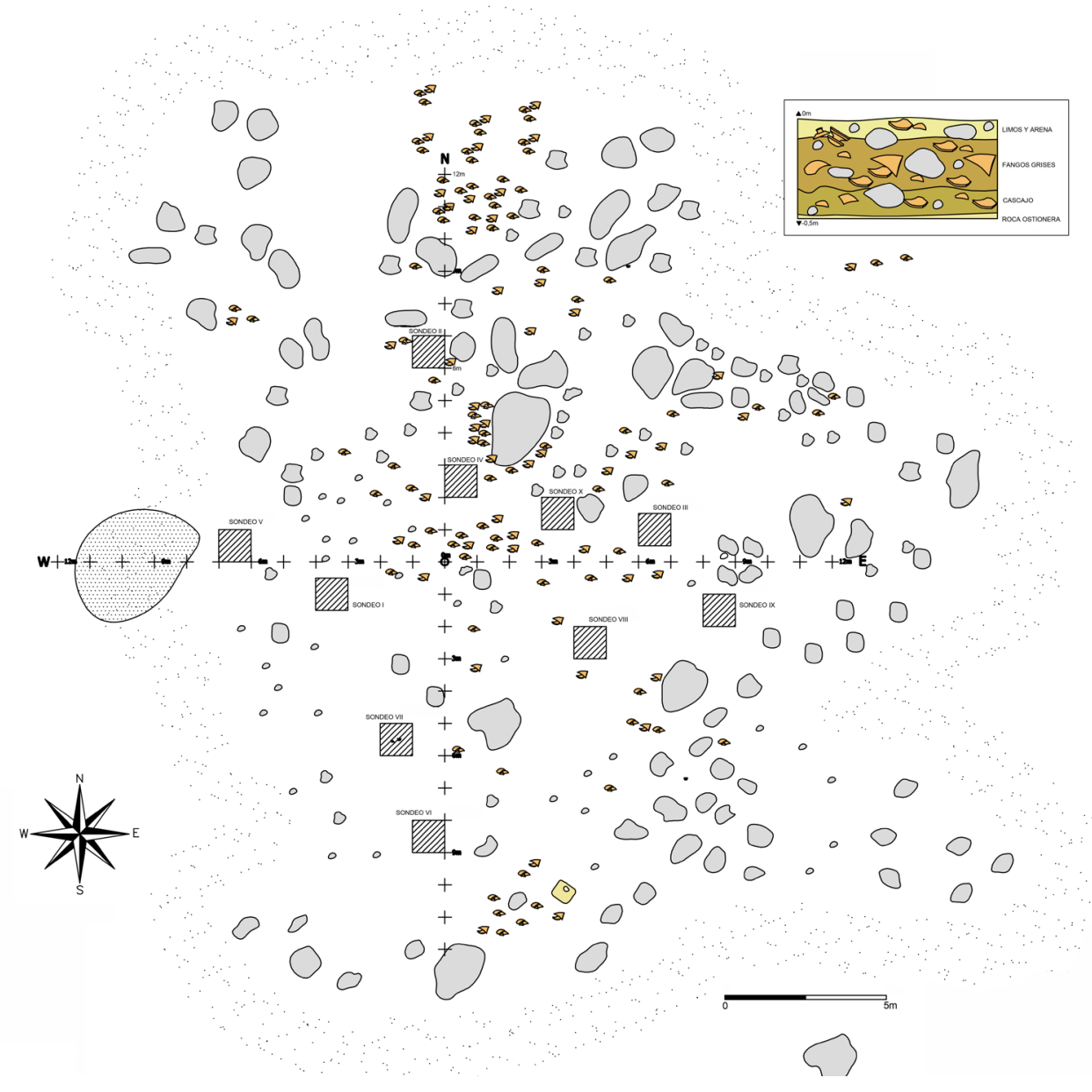

Figura 3: Plano de localización de los sondeos y de dispersión de los hallazgos cerámicos registrados en Canal del Sur (planimetría original de E. Toboso y A. Higueras-Milena).

localizaciones diferenciadas), con el objetivo esencial de delimitar con mayor precisión algunas concentraciones importantes de objetos cerámicos y contribuir a la identificación cronológica y tipológica de los diversos yacimientos (permitiendo así una evaluación concreta de su potencial de cara a ulteriores fases de actuación e investigación).

Debemos comenzar señalando que, desgraciadamente, las actividades de prospección geofísica y arqueológica no permitieron documentar evidencias claras de la presencia de pecios de época prerromana en todo el sector estudiado pese a la abundancia de localizaciones que sí proporcionaron materiales de esta cronología. La aplicación de métodos electromagnéticos en el citado anteriormente «Pecio de Juan Villa» para constatar la presencia o ausencia de objetos arqueológicos sobre el fondo o soterrados, a partir de las posibles alteraciones del campo magnético a causa de las concentraciones de cerámicas resultó negativa, y tampoco se detectó material arqueológico en las prospecciones visuales y sondeos, llevados a cabo en 2009 y 2010. Sin embargo, en el registro del sonar de 2008 se puede delimitar una anomalía de $40 \times 16$ m sobre la que será necesario concentrar nuevos esfuerzos en futuras campañas en condiciones más favorables a fin de confirmar o descartar la presencia de un pecio púnico en este punto.

La prospección arqueológica visual por medio de buceadores se utilizó como vía para revisar las anomalías detectadas en la fase previa de prospección geofísica (Fig. 2), pero también con el objetivo de obtener datos en aquellas zonas en las que no se habían obtenido buenos resultados con la aplicación de dichas técnicas debido a las particularidades de los diversos fondos y a las adversas condiciones climatológicas. Se utilizaron para esta fase de revisión en forma de prospección visual diferentes técnicas: prospección lineal, círculos concéntricos y rumbos. Estas prospecciones se realizaron entre los años 2008 a 2010, principalmente durante los meses de mayo a septiembre buscando las mejores condiciones de mar posibles, realizándose los trabajos a bordo del buque «Trafalgar» y con la asistencia de la embarcación del Centro de Arqueología Subacuática (IAPH) de la Junta de Andalucía.

Como complemento a las prospecciones, en los puntos en los que se localizaron indicios de mayor importancia se realizaron también sondeos estratigráficos de comprobación con el fin de precisar la naturaleza cronológica y tipológica de los yacimientos detectados en las localizaciones de La Cepera, Punta 
del Nao y Canal del Sur, y asimismo con el objetivo de delimitar espacialmente los mismos para su adecuada evaluación arqueológica y el establecimiento de medidas de cautela y protección administrativa. Se practicaron cuadrículas de pequeña extensión (1x1 m) que se posicionaban con GPS desde la embarcación o con sistema de triangulación con respecto a puntos cero preestablecidos (Fig. 3). La excavación de estas catas se desarrolló utilizando criterios estratigráficos o mediante niveles artificiales, según las condiciones de visibilidad y de movilidad de los fondos así lo permitiesen, primándose el primero de estos sistemas. La extracción de los áridos se realizó con una manga de succión y el sedimento desplazado, una vez descartada la presencia de restos arqueológicos, se utilizó con posterioridad para cubrir los sondeos finalizados.

A pesar de las prometedoras condiciones de estas concentraciones, en las cuales a priori no resultaba posible determinar si realmente se trataba de material in situ (pecio o zona de depósito) o resultado de procesos post-deposicionales (arrastre de las corrientes, etc.), los sondeos no permitieron documentar rastro alguno relacionado con naves de época antigua ni clarificar la naturaleza concreta de estas concentraciones (cuyos componentes mostraban en algunos casos una notoria diacronía y heterogeneidad tipológica). No obstante, el análisis espacial de estas localizaciones ha permitido catalogar con más amplitud un significativo conjunto de yacimientos de cara a su inclusión en el Sistema de Gestión e Información de los Bienes Culturales de Andalucía (MOSAICO) y al establecimiento de medidas de cautela y futura intervención. El resto de materiales incluidos en este trabajo procedentes de Laja Herrera y del Bajo de Chapitel proceden de la fase de prospección, y se documentaron de forma dispersa y sin una asociación clara entre sí o a estructuras de algún tipo.

\section{ESTUDIO DE LOS MATERIALES}

Los trabajos de prospección y sondeo permitieron recuperar una importante cantidad de ítems de muy diversa cronología, fundamentalmente cerámicos, cuya cifra total ascendió a 634 piezas. La mayor parte de ellas fueron documentadas en el curso de la campaña de 2009 (451) y 2010 (167), correspondiendo en gran medida a evidencias del uso del entorno de La Caleta y sus bajos aledaños como foco portuario en la Antigüedad. Si exceptuamos, como desarrollaremos más adelante, los recuperados en las proximidades de la Punta del Nao, la mayoría de estos objetos pueden ser identificados como elementos propios del trasiego marítimo desarrollado a lo largo del I milenio a.C., y particularmente de su segunda mitad. Se presenta a continuación un examen pormenorizado de estos ítems correspondientes grosso modo a la «fase púnica» de Gadir, es decir, a la comprendida entre el tramo final del siglo VI a.C. y el final del III a.C. Se trata, como es ampliamente conocido, de una fase de enorme crecimiento y proyección exterior de la bahía gaditana, por lo que el estudio de estos objetos trasciende el interés que pueda tener en el marco estrictamente local para proporcionar datos sobre la evolución del comercio atlántico-mediterráneo de la época.

\subsection{CANAl Del SuR}

A partir de la inspección de varias anomalías del Sonar de Barrido Lateral (SBL) en la zona denominada Canal del Sur, se realizaron una serie de prospecciones visuales en las que se documentó una importante dispersión de restos cerámicos púnicos y romano imperial, que posteriormente fue objeto de sondeos. Es necesario recordar que en el curso de las actuaciones de 2008-2010 fueron aisladas varias concentraciones distribuidas en torno a este punto. La más occidental (Canal del Sur 1) proporcionó abundante material anfórico, sobre todo púnico y romano imperial, con presencia de pebeteros de doble cazoleta, anforillas en miniatura y vajilla común y barnizada de épocas diversas (incluyendo cerámicas comunes, de cocina y ARSW D) mostrando un elenco material muy diverso con una cronología de amplia diacronía (siglos $\mathrm{V}$ a.C. a $\mathrm{V} \mathrm{d.C}$.). Al oeste de este punto se pudo individualizar otra concentración de materiales de gran interés (Canal del Sur 5) aparentemente agrupados en un radio de unos $10 \mathrm{~m}$, mucho más abundantes que en la anterior, con un claro predominio de elementos correspondientes a la etapa púnica inicial y a momentos transicionales a la fase romano-republicana.

En el caso de Canal del Sur 1 los restos anfóricos más antiguos corresponden a algunos individuos del tipo T-11213 de producción gaditana (Fig. 4) representados por fragmentos en diverso estado de conservación, incluyendo asas (CSUR/CA09/32) junto a porciones correspondientes al cuarto superior (CSUR/ CA09/04). En concreto, este último individuo muestra una morfología de borde triangular macizo propio de momentos plenos del siglo V a.C., con asas de tamaño notable dispuestas sobre la carena que separa la espalda del cono superior, sugiriendo que nos encontramos ante un ánfora del horizonte definido en las fases plenas-tardías de Camposoto (Ramon et alii, 2007) o en depósitos bien conocidos como el Punic Amphora Building de Corinto (Zimmerman-Munn, 2003). Sin que podamos estar en ningún caso seguro de si existió contemporaneidad entre ambos, al tramo final del siglo $\mathrm{V}$ a.C. pertenece probablemente un fragmento de borde, pared y asa de un ánfora de fábrica gadirita que parece inspirarse en el perfil de las T-1323 ebusitanas y que constituye un primer eslabón de la cadena tipológica que daría origen a las T-8211 propias del siglo IV a.C. (CSUR/CA10/82, Fig. 7).

Está presente también en el conjunto de materiales recuperado alguna versión miniaturizada de estos perfiles, también con pastas aparentemente locales (CSUR/CA09/41) y cuyo perfil parece definir formas similares a las de los prototipos de talla habitual 

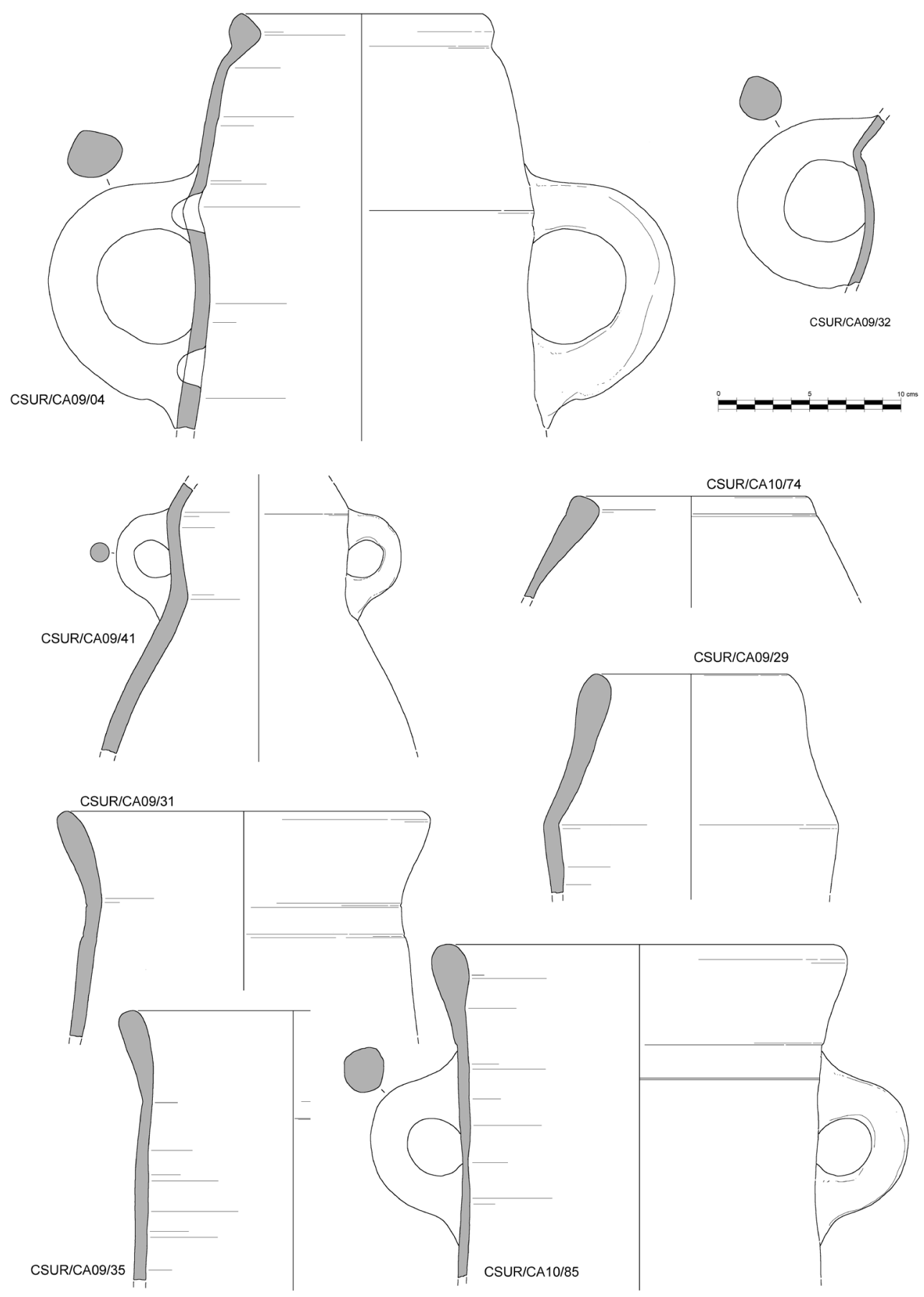

Figura 4: Anforilla en miniatura y envases de transporte T-11213, T-8211 y T-12111 de Canal del Sur 1.

descritos. Se trata de ítems ampliamente conocidos en los registros subacuáticos de la zona desde hace décadas, como ha sido puesto de manifiesto en el apartado historiográfico, y que la investigación reciente ha permitido vincular al posible transporte de contenidos alimentarios selectos y asimismo resituar en un amplio marco cronológico entre los siglos V-III a.C. (Niveau, 1999; Gutiérrez, 2000; Sáez Romero, 2008).

A estos horizontes cronológicos de Canal del Sur 1 pueden asociarse también otros materiales no anfóricos de gran interés, caso de dos individuos que corresponden a tinajas quizá vinculadas con la familia de los derivados de los pithoi arcaicos que pueden quizá ponerse en conexión con las T-11213 o incluso en momentos algo posteriores (Fig. 5). Se trata de dos versiones de tinajas biansadas de cuerpos con tendencia acilindrada, en un caso con el arranque de las asas (de sección aplanada) sobre el borde proyectado al exterior de forma caso triangular (CSUR/CA09/06) y en otro caso con un cuerpo mucho más cilíndrico rematado en un borde triangular también prominente pero con asas situadas directamente sobre el galbo, 

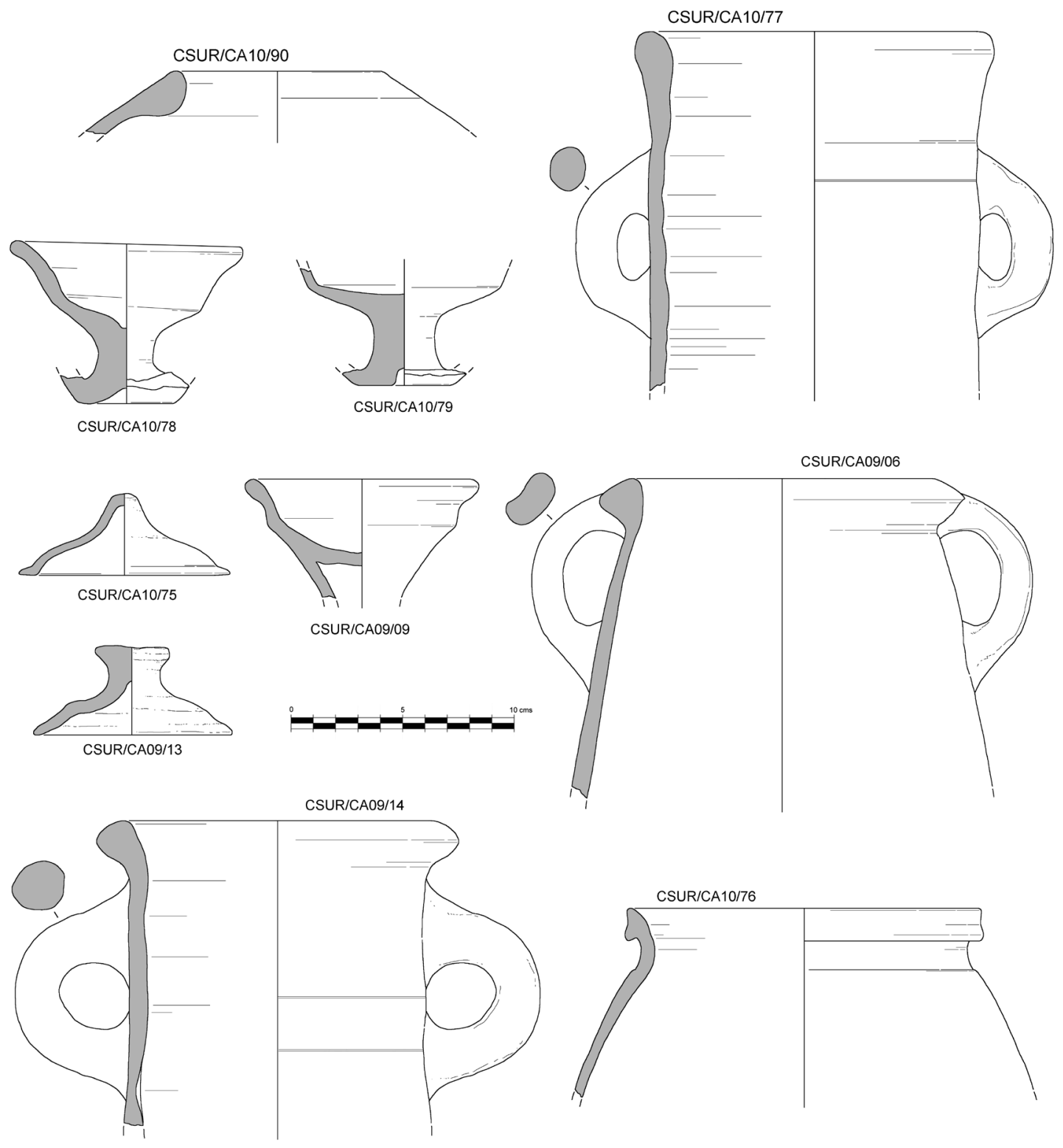

Figura 5: Materiales cerámicos procedentes de Canal del Sur 1: ánfora turdetana Pellicer D, ánfora local T-8211 tardía, tinajas de diversa tipología, pebeteros de doble cazoleta y tapaderas.

contando éstas con sección circular un una morfología semicircular muy similar a las de las ánforas T-8211 quizá contemporáneas (CSUR/CA09/14). En ambos casos es posible relacionar estas producciones con manufacturas locales conocidas en algunos talleres estratigráficamente significativos, caso de Camposoto (tipos XIa2-3 o XIb3-4; Ramon et alii, 2007) o Villa Maruja (Sáez Romero, 2014a), que permiten situar cronológicamente estos derivados de las tinajas arcaicas entre el pleno siglo $\mathrm{V}$ y las primeras décadas del siglo IV a.C. Como ya se ha avanzado en trabajos anteriores, estos ítems comunes de fondo rehundido podrían representar el estadio más inicial de formas anfóricas de transporte que eclosionarían y ganarían gran protagonismo en la etapa tardopúnica, y en especial podrían ser las formas precursoras de las versiones iniciales de las T-9111 del siglo III a.C. (Sáez Romero, 2008), por lo que no debe extrañar su presencia en estos contextos subacuáticos quizá como muestra de su temprana participación activa en los fletes mercantiles de fases anteriores sirviendo ya como recipientes de transporte comercial.

El resto del material anfórico recuperado en Canal del Sur 1 se puede encuadrar cronológicamente en fases más tardías, caracterizando la circulación marítima en este entorno portuario en la etapa púnica tardía o romano-republicana inicial. Destaca el conjunto de envases del tipo T-8211 con diámetros anchos y labios 
diferenciados por suaves incisiones o resaltes (CSUR/ CA09/31-35 y CSUR/CA10/85) que parecen apuntar a una deposición en estas aguas en momentos avanzados del siglo IV o fases iniciales del III a.C. (Sáez Romero, 2014b). De esta misma serie anfórica también encontramos algún ejemplar de diámetro más reducido y asas pequeñas que sugiere incluso una cronología más tardía, ya en el tramo final del siglo III o más probablemente durante el II a.C., con labios casi indiferenciados y muy verticales (CSUR/CA10/77). Es posible que algunos otros individuos recuperados en la zona puedan ser contemporáneos de estas T-8211, particularmente un ejemplar de T-12111/2 (Niveau, 1999; Sáez Romero, 2008) con un labio engrosado al interior y la característica incisión fina en la cara superior externa, elementos propios de producciones sobre todo del siglo III a.C. (CSUR/CA10/74). Asimismo, cabe citar también la presencia en el conjunto de una T-12111 de líneas simples, con borde indiferenciado y hombros con carena suave (CSUR/CA09/29), cuya pasta parece denunciar un origen regional exógeno (siendo por tanto un elemento consumido o redistribuido a través del puerto gadirita).

Una tinaja de pasta gaditana de borde triangular y cuerpo ovoide cercana al tipo GDR-8.1.1 (Sáez, 2008) también podría ubicarse en este lapso, aunque la presencia de un resalte o pequeña depresión a modo de «cuello» podría sugerir que se trata de una variante algo anterior (CSUR/CA10/76), propia de horizontes caracterizados por ejemplo en talleres como Villa Maruja en los siglos IV-III a.C.

Probablemente al tramo cronológico situado entre el final del siglo III y la primera mitad del II a.C. pertenece un borde de un ánfora turdetana del tipo Pellicer $\mathrm{D}$ evolucionado, que muestra las características propias de los estadios más tardíos de su producción en el entorno de la propia bahía y campiña gaditana (CSUR/ CA10/90), con un borde apenas diferenciado al exterior por un leve resalte y engrosado con forma redondeada al interior (Niveau, 2002; Sáez y Niveau, 2014). La presencia de este tipo de envases en los yacimientos terrestres del arco de la bahía gaditana es bien conocida, siendo tremendamente abundantes en contextos de hábitat, en áreas funerarias (incluso como parte de las cubiertas de los enterramientos; Niveau, 2009) y también en vertederos vinculados a zonas de producción alfarero-salazoneras (Sáez Romero, 2008 y 2014a).

Aunque sus puntos de producción no están por ahora del todo clarificados, se sospecha que estos envases pudieran haber transportado contenidos alimentarios alternativos a las salazones obtenidos en los propios rebordes de la bahía y en las campiñas adyacentes al Bajo Guadalete o el Iro, participando del abastecimiento de la bahía de forma capital tomando formas anfóricas propias del Bajo Guadalquivir. La presencia de este fragmento en contexto subacuático en una zona vinculada íntimamente al trasiego portuario de Gadir resulta relevante dado que supone una nueva muestra, quizá la más evidente, de la comercialización ultramarina de estas ánforas desde la base del puerto de Gadir, probablemente compartiendo flete con los propios envases locales T-8211, T-12110 y/o T-9111, tal y como había sido sugerido anteriormente en base a la presencia de estas ánforas en números exuberantes en el norte de la Mauritania occidental, en las costas del Algarve o incluso en el noroeste ibérico.

En esta etapa púnica (sin descartar una cronología más antigua para algunos de estos elementos) se podrían encuadrar también los tres ejemplares de quemaperfumes de doble cazoleta y dos pequeñas tapaderas de fábrica local recuperadas en esta zona, objetos ampliamente conocidos en toda el área de La Caleta en relación a posibles ofrendas o ceremoniales rituales desarrollados en sus aguas que conllevarían la deposición de estos elementos a su término (Ramírez, 1982; Corzo, 1983; Pérez Hormaeche, 1990; Muñoz, 1993). Se trata en el caso de las tapaderas (CSUR/CA09/13 y CSUR/CA10/75) de dos variantes diferentes de pequeño diámetro y pomo hueco, probablemente ajustadas a encajar con los propios pebeteros a fin de cubrir la cazoleta superior como muestra el ejemplo documentado in situ en la Casa del Obispo (Gener et alii, 2014).

Por su parte, los quemaperfumes presentan también una morfología diversa, con vástagos centrales prácticamente macizos (CSUR/CA10/78), sólo tímidamente huecos (CSUR/CA10/79) o completamente huecos (CSUR/CA09/09), aunque en todos los casos el cuenco superior parece de mayor diámetro que el inferior y presenta la típica morfología carenada y abierta. Como es bien sabido, estos pebeteros se encuentran representados en contextos cultuales (Maya et alii, 2014), habitacionales (Córdoba y Ruiz, 2005) o funerarios (Ruiz y Pérez, 1995a; Sáez y Belizón, 2014) de la bahía gaditana arcaica, aunque también se constata su producción al menos durante el siglo $\mathrm{V}$ a.C., como ejemplifica el caso del alfar de Camposoto (Ramon et alii, 2007, 90, fig. 160), si bien no existen evidencias para los siglos IV-III a.C. Por ello, y ante la falta de una asociación contextual clara, resulta difícil precisar la datación de estos elementos, quizá mayoritariamente tardoarcaicos.

Como en el caso anterior, en Canal del Sur 5 también se detecta la presencia de algunos elementos de cronología arcaica que podrían estar denunciando no sólo el tráfico desarrollado en esta etapa hacia o desde el interior de la bahía sino también la existencia de procesos de deposición intencional de ítems en este punto cercano a los santuarios del oeste de la Erytheia. En concreto, debemos destacar la presencia de al menos un ejemplar de ánfora «de saco» del tipo T-10121 representada por un borde triangular macizo (CSUR/ CA10/41), la cual parece responder a las morfometrías propias del pleno siglo VII o las décadas iniciales del VI a.C. y algunos individuos de dipper juglets de diversa tipología y origen (dados a conocer en Sáez e Higueras-Milena, e.p., los cuales encuentran paralelos entre las cerámicas documentadas en el cercano Castillo de San Sebastián; Maya et alii, 2014). 

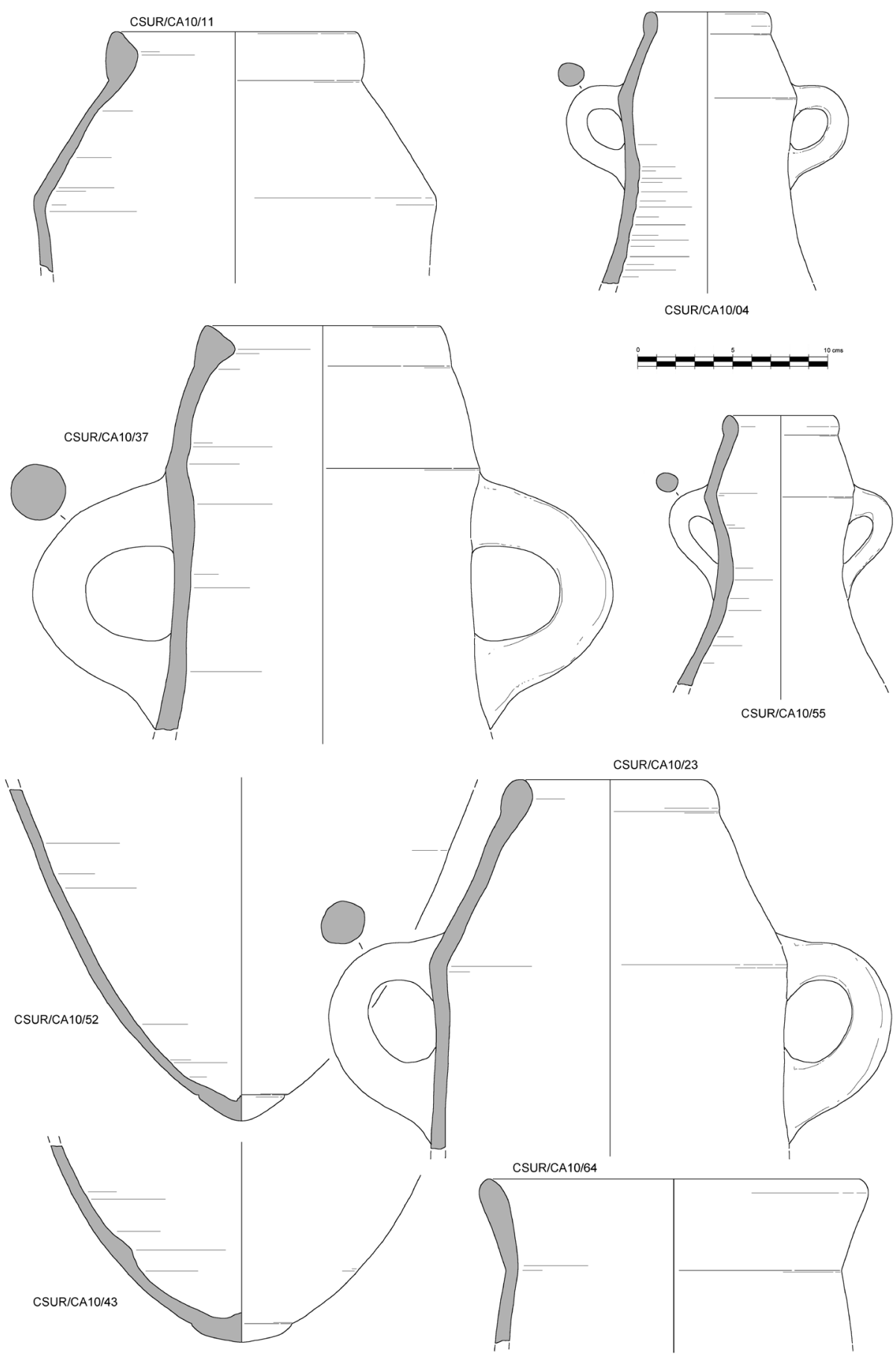

Figura 6: Materiales cerámicos de Canal del Sur 5: anforillas en miniatura, ánforas T-11213, T-11216, T-12111 y T-8211.

Una parte significativa de los hallazgos anfóricos registrados puede situarse en un momento tardío del siglo V a.C., dejando entrever la posible existencia de una agrupación de materiales de este horizonte que quizá sugiera la existencia de un pecio o un momento álgido de tráfico en la zona (Fig. 6). Entre estos materiales destaca la presencia de un individuo de T-11213 de labio triangular y paredes muy finas, de pasta local (CSUR/CA10/11), así como algunos fondos de T-11214/5 o T-12111 iniciales dotados del característico botón o resalte exterior propio de estos horizontes en la transición entre los siglos V-IV a.C. (CSUR/ CA10/43 y 52). Junto a estos elementos de fábrica gadirita, dos ejemplares de ánforas de similar perfil pero miniaturizadas (CSUR/CA10/04 y 55), cuya datación es, como ya se ha dicho a propósito de Canal del Sur 1, desafortunadamente incierta. En cualquier caso, sí es posible ligar con cierta seguridad a esta facies del tardío siglo V a.C. un individuo de T-11216 importado, con labio triangular y asas de $2 / 3$ de círculo situadas por debajo del nivel de la carena de los hombros, denotando la pasta un posible origen mauritano o de 

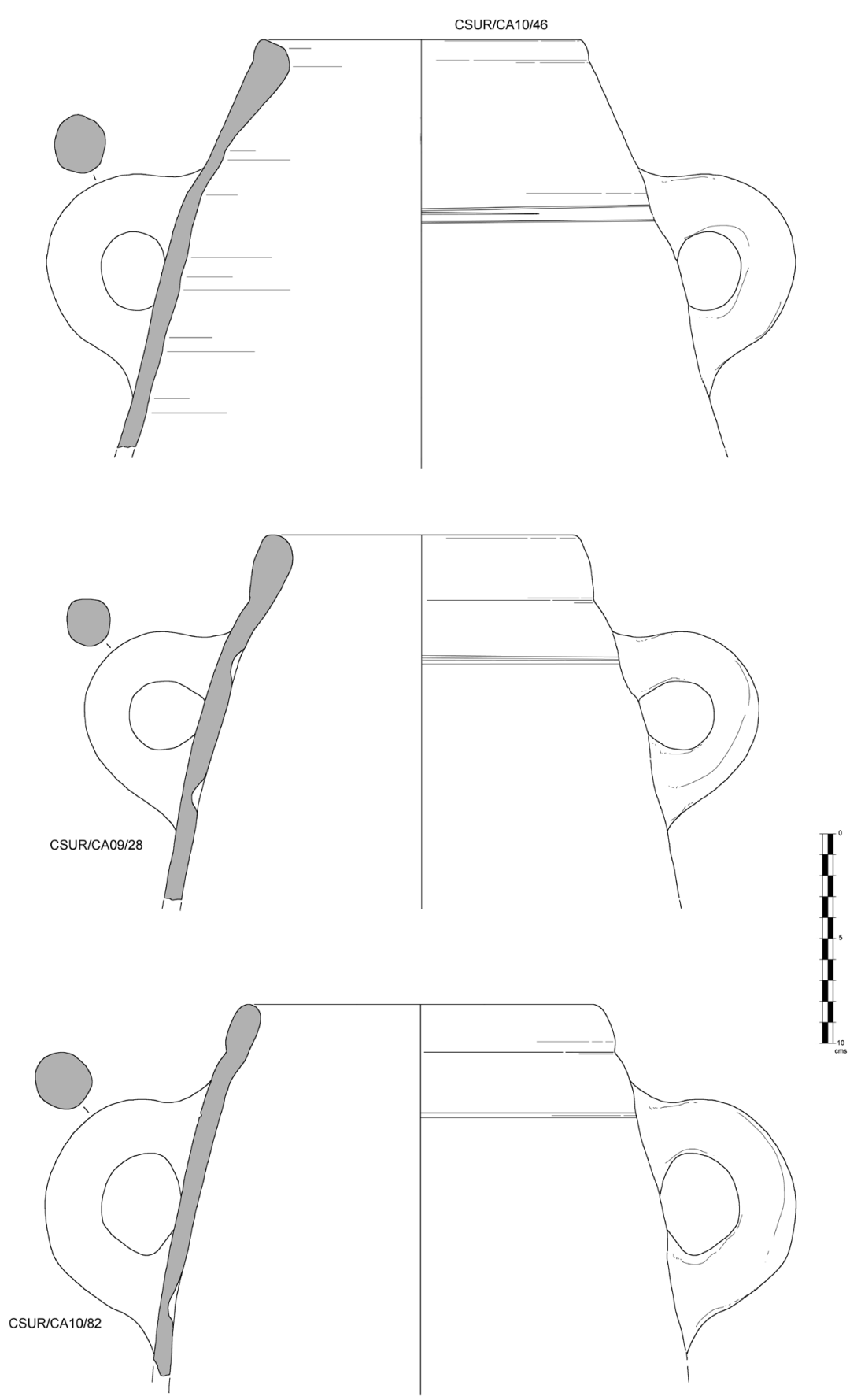

Figura 7: Envases anfóricos relacionados con las versiones gaditanas del modelo ebusitano T-1323 documentadas en Canal del Sur 5 y Canal del Sur 1 (CSUR/CA10/82).

la parte mediterránea de la región (CSUR/CA10/37). Se trata por otra parte de una combinación de ánforas bien conocida en contextos terrestres gaditanos, especialmente en ambientes industriales de la bahía (Sáez Romero, 2014a), pero también en naufragios bien estudiados como el pecio ibicenco de Tagomago 1 (Ramon, 1985 ; 1995) que ilustran la existencia de fletes en las que las ánforas de fábrica gadirita compartían bodegas en dirección al Levante y Mediterráneo central con T-11216 de talleres inciertos de la región del Estrecho.
A estos ingredientes debemos sumar además la presencia de al menos otro ejemplar de ánfora local que parece imitar a sus contemporáneas ibicencas T-1323 (Fig. 7), colocándose como precedentes directos de las primeras T-8211 típicas del siglo IV a.C. (Sáez Romero, 2014b). En concreto, se trata de un individuo con bordes cortos, apenas desarrollados y diferenciados del cuerpo apenas por una leve depresión, con unas bocas relativamente estrechas motivadas por un galbo claramente invasado (CSUR/CA09/28), mientras que las asas son de buen tamaño y su arranque superior 
aparece indicado por una característica incisión practicada precocción. Otro individuo, cuya pasta no permite determinar con total certeza su origen local (CSUR/ CA10/46) presenta unas características tipológicas similares en cuanto a morfología del cuerpo, incisiones y tamaño, pero presenta un borde aún más cercano a los ejemplares ebusitanos -más indiferenciado- y se asemeja incluso más a las ánforas de la propia serie $\mathrm{T}-12111$ local (atendiendo a sus rasgos, no es en absoluto descartable que pueda tratarse de las primeras versiones de la serie conocida como Tiñosa/T-8112; Cf. Carretero, 2007). En cualquier caso, se trata de envases de transporte claramente datables en el tramo final del siglo $\mathrm{V}$ a.C., contemporáneos a la producción local de las últimas T-11213 y las T-11214/5, y posiblemente también a la fabricación de las T-11216 en puntos no determinados del Estrecho meridional o mediterráneo.

Un heterogéneo conjunto de cerámicas comunes y de cocina podría estar asimismo ligado a estos horizontes púnicos plenos, aunque como resulta crónico en este análisis de materiales la falta de asociaciones precisas impide cualquier aseveración definitiva en este sentido (Fig. 8). Sí parece muy probable en el caso de una tinaja biansada, similar a las documentadas en Canal del Sur 1, de nuevo con un cuerpo estrecho y acilindrado, borde triangular ligeramente colgante al exterior y asas de notable volumen, en esta ocasión partiendo del propio labio y con una sección marcada por un surco central poco profundo (CSUR/CA10/70). Son asimismo significativas las incisiones horizontales, agrupadas, presentes a la altura del arranque inferior del asa, elementos que junto a las restantes características enumeradas acercan a esta tinaja a las producciones del tipo XIa2-3 del alfar de Camposoto (Ramon et alii, 2007, 91), por tanto propias del siglo $\mathrm{V}$ a.C., aunque con perduración posterior al menos hasta los inicios del IV a.C. según sugieren los vertederos del entorno de Villa Maruja. Otros individuos presentes en Canal del Sur 5 no encuentran referentes tipológicos tan evidentes, caso de una posible jarra mediana de fondo plano, acaso una versión local de un tipo griego (CSUR/CA10/51) o una tinaja o pithos evolucionado de gran volumen y paredes relativamente finas (CSUR/CA10/24). Respeto a las cerámicas de cocina, el ejemplar de menores dimensiones (CSUR/ CA10/66) es quizá el más claro ejemplo de todas las ollas presentes en el área de recipiente de cocción globular propio de momentos arcaicos avanzados o tardo-arcaicos, con referentes tanto para la fase colonial avanzada (Ruiz y Pérez, 1995b) como para la etapa púnica (producciones de Camposoto tipo DIVa1-2 y también de Villa Maruja; vide Ramon et alii, 2007; Sáez Romero, 2010). El resto de ollas recuperadas ${ }^{4}$ repite este esquema de tendencia globular con labios más o menos redondeados vueltos al exterior, siendo

4. Con números de inventario CSUR/CA10/29, 32, 48, 49, 50, 65 y 68. en todos los casos de unas dimensiones mucho mayores y careciendo de las características incisiones en la transición entre cuerpo y borde (lo que hace que no podamos estar del todo seguros de su atribución tipológica en algunos casos, como de su datación).

En un escalón cronológico levemente inferior encontramos otras ánforas de fábrica local cuya tipología sugiere que en ambos casos pudieran corresponder a horizontes de producción y comercialización de las salazones gaditanas del tramo central o segunda mitad del siglo IV a.C. En concreto, nos referimos a un cuarto superior de una T-12111 de labio redondeado y cono superior acilindrado (CSUR/CA10/23) y un borde de una T-8211 de boca ancha sin incisiones en la parte alta del cuerpo (CSUR/CA10/64) (Fig. 6). Se trata de tipologías ampliamente documentadas en talleres cerámicos de la mitad meridional de la isla gaditana, y en especial en depósitos de testar de Villa Maruja o Torre Alta, así como también en asociación en contextos de vertedero de diversos saladeros de pescado de la bahía (Sáez Romero, 2014a). Un último horizonte cronológico, quizá denunciando la presencia de un naufragio en este punto, puede ser diferenciado en base al amplísimo conjunto de anforillas del tipo T-9111 recuperadas en esta zona de Canal del Sur, cuyas tipologías sugieren dataciones desde el final del siglo III a.C. y durante el II a.C. (Higueras-Milena y Sáez, e.p.).

De forma necesariamente genérica entre la fase arcaica y los inicios del periodo púnico cabe situar también el numeroso conjunto de ítems de pequeño porte (Figs. 9-10) conformado por quemaperfumes, tapaderas y un platito-tapadera simple (CSUR/CA10/07). Los pebeteros presentan la habitual diversidad tipológica bien conocida en otros hallazgos anteriores del entorno de La Caleta (Pérez Hormaeche, 1990; Muñoz, 1993), predominando perfiles con vástagos no demasiado desarrollados y huecos, cazoletas inferiores de menor diámetro que las superiores y cuencos superiores carenados de escasa profundidad y labios exvasados $^{5}$, aunque no faltan ejemplares muy toscos con astiles macizos (CSUR/CA10/42) o desprovistos de cazoleta inferior (CSUR/CA10/30). En cualquier caso, la tipología remite a formas aparentemente evolucionadas desde los perfiles fenicios arcaicos, sin que se aprecie en ninguno de los individuos de Canal del Sur trazas de engobados totales o parciales. Formando probablemente pareja funcional con estos quemaperfumes comparecen en este depósito diversos ejemplos de pequeñas tapaderas de similar diámetro, con paredes sinuosas o carenadas y pomos más o menos desarrollados (CSUR/CA10/08, 14 y 58), que en algunas ocasiones permiten incluso el apoyo invertido de la tapadera para convertirla en un pebetero de un sólo cuenco superior (caso de CSUR/CA10/02 y 15). Además de estos ejemplares se documenta otra variante

5. Los números de inventario corresponden a CSUR/CA10/08, $09,10,16,17,24$ y 30. 


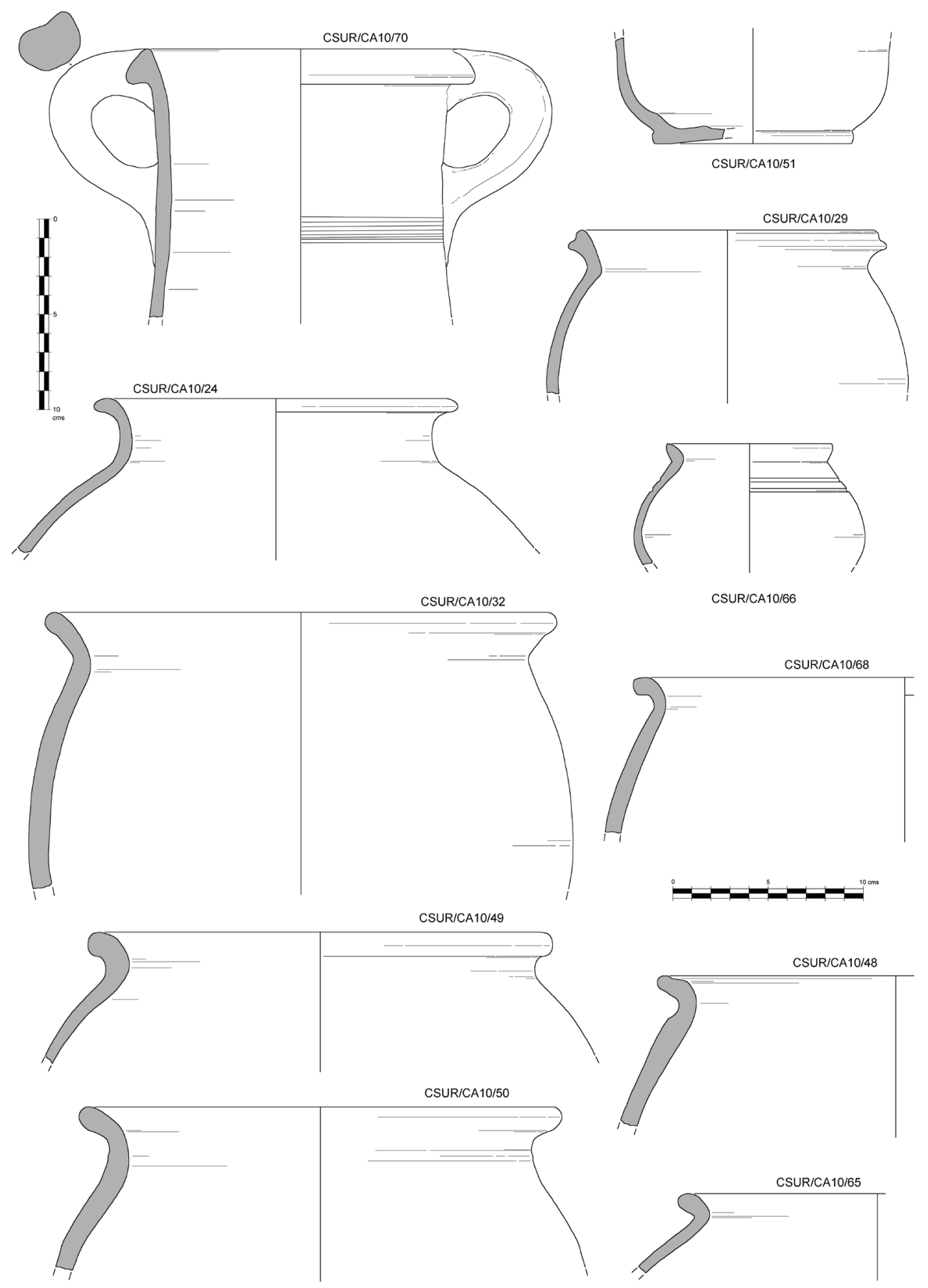

Figura 8: Material no anfórico de Canal del Sur 5: tinaja biansada acilindrada, fondo de jarra, tinaja sin asas y diversos tamaños de ollas de pastas toscas.

aún más simplificada con pomo hueco y pared casi recta rematada en un borde biselado, cuyo encaje cronológico resulta aún más problemático que las anteriores (CSUR/CA10/18). Como ya se apuntó respecto del caso de Canal del Sur 1, la abundancia de estas series de pebeteros en contextos arcaicos y en alfarerías tardoarcaicas de la bahía no permite concretar su datación.

Junto a este conjunto muy homogéneo debemos resaltar la presencia de algunos otros elementos relacionados de interés. Por un parte, un vástago hueco similar a los observados en el caso de los quemaperfumes pero de mayor desarrollo vertical, que podría no obstante pertenecer a otro de estos pebeteros o a una lucerna de tipo fenicio dispuesta sobre este astil (CSUR/CA10/12), similar a ejemplos arcaicos orientales (Núñez, 2013, 32-33, fig. 5e). Más interesante aún resulta la documentación de un soporte compuesto por un platillo con un vástago hueco central rematado en un borde simple exvasado, muy similar al perfil 

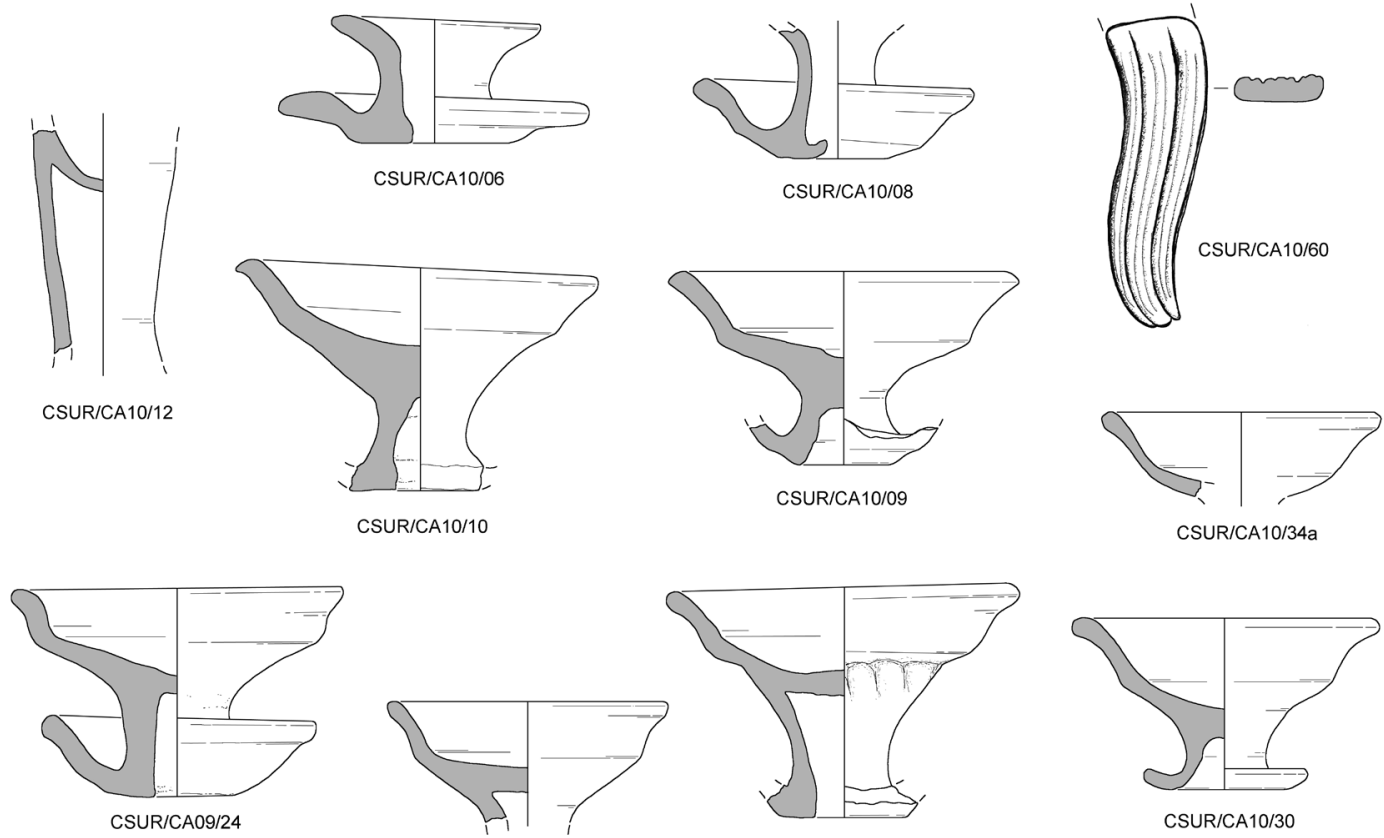

CSUR/CA10/17
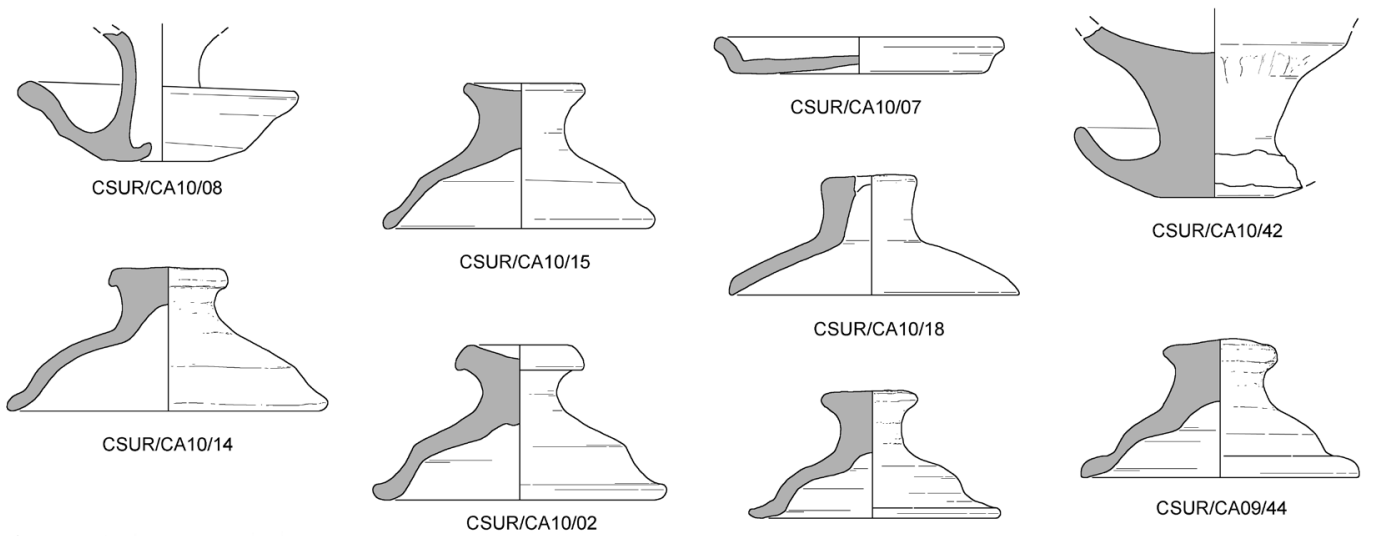

CSUR/CA10/58

Figura 9: Material no anfórico de Canal del Sur 5: posible fragmento de terracota, pebeteros de doble cazoleta, astil de otro posible pebetero, piatto «a bugia», platito poco profundo y tapaderas de diversa tipología.

general de los pebeteros (CSUR/CA10/06) pero identificable con prototipos de soportes-tapadera bien conocidos en los registros de Cartago y del área púnica centromediterránea (Cintas 1950) especialmente en el ámbito de sus necrópolis de cremación o tofets ${ }^{6}$. La

6. En la historiografía italiana estos ítems son conocidos como piattini a «bugia», documentándose desde el siglo VII a.C. hasta la etapa tardopúnica sobre todo como tapaderas para cubrir las urnas cinerarias, con numerosos ejemplos en Malta, Cerdeña o Cartago (Acquaro, 1999, 23; quien propone una progresiva reducción del diámetro a partir del siglo IV a.C.). Estos platillos están presentes en Iberia también en ajuares funerarios como el de la cámara Trayamar 1 (Schubart y Niemeyer, 1976, lám. 12). Siguiendo el esquema propuesto por Acquaro, el ejemplar de Canal del Sur encajaría con producciones tardías no anteriores a los siglos V-IV a.C. combinación soporte/lucerna ha sido documentada en la propia Gadir en un contexto interpretado según algunos autores como de vocación funeraria datado en el siglo V a.C. (Muñoz, 2002, 32, $n^{\circ}$ 6) y para otros de carácter votivo-cultual en momentos tardopúnicos (Niveau y Córdoba, 2003, 139-140, fig. 12), lo que no permite en ningún caso descartar cualquier vía para explicar la llegada de esta pieza a los fondos del Canal del Sur. En este caso, y dada la lejanía de la paleocosta en época fenicia no resulta muy probable que este ítem provenga de un posible enterramiento devorado por la erosión marina, sino más bien que formase parte de un conjunto aun no localizado, en las inmediaciones de la concentración analizada.

A estos elementos de posible uso cultual podemos unir además un fragmento de una posible terracota, de la cual apenas se conserva lo que parece un fragmento 

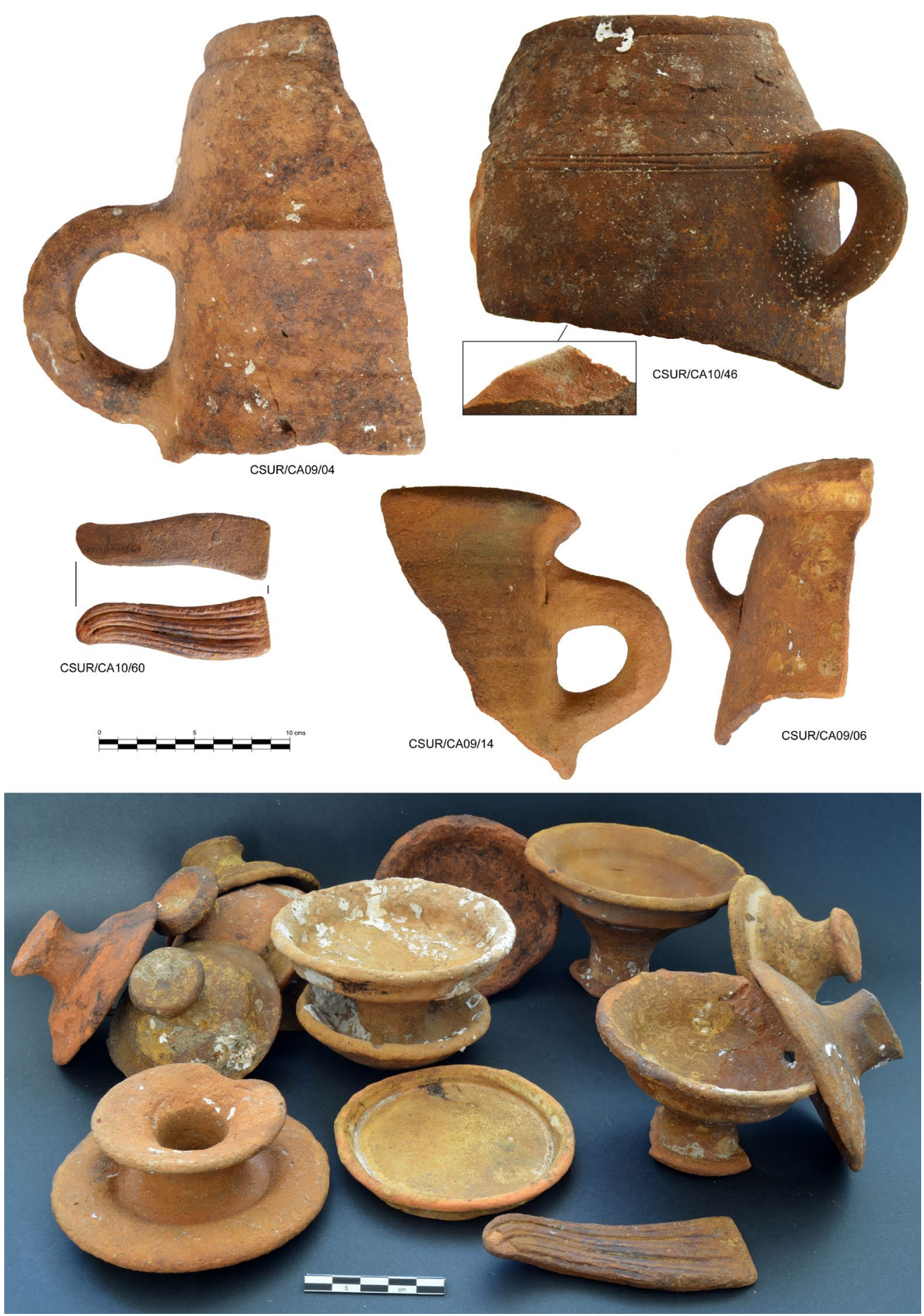

Figura 10: Fotografías de diversos materiales de Canal del Sur: ánfora T-11213, ejemplar de tipología cercana a T-1323 con detalle de la pasta, fragmento de posible terracota, tinajas anforoides y conjunto de pebeteros, tapaderas y platitos.

de bucle del pelo (Figs. 9 y 10), a modo de rizo de sección aplanada que debió desprenderse de las capas más externas de la figura debido a la acción marina (CSUR/CA10/60). Pocas precisiones pueden hacerse sobre este ítem, sobre cuya cronología o atribución formal no podemos estar seguros debido a la evidente fragmentación y a la falta de asociación contextual, aunque cabe no perder de vista la proximidad formal del bucle recuperado en 2010 con el pelo de la considerada como Venus Marina procedente también de las aguas de La Caleta (Corzo, 1999).

\section{2. LA CEPERA}

En esta localización se recuperó un sugerente conjunto de fragmentos de ánforas y otras cerámicas de datación arcaica (analizados en Sáez e Higueras-Milena, e.p.), 


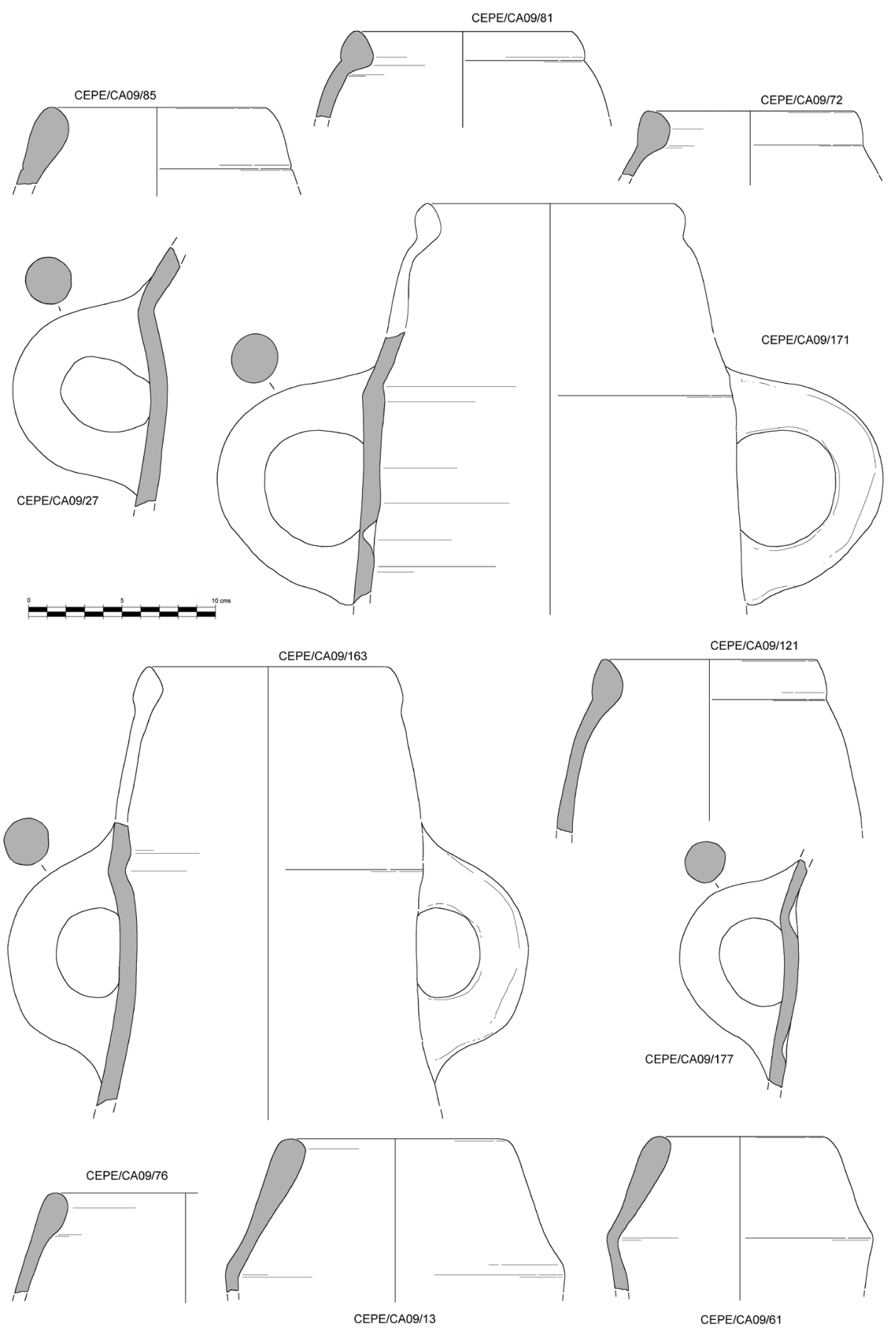

Figura 11: Ánforas documentadas en La Cepera: bordes y asas del grupo T-11210 y bordes de la serie T-12110.

si bien como en el caso de Canal del Sur, otra buena parte de los materiales recuperados parece poder situarse cronológicamente entre el pleno siglo $\mathrm{V}$ y los inicios del IV a.C., y no faltan testimonios que permiten alargar la frecuentación del fondeadero mucho más allá dentro de la fase prerromana denotando una etapa de intenso tráfico comercial marítimo correspondiente al floruit de la industria pesquero-conservera local.

En relación a la fase púnica, debemos destacar la recuperación de varias ánforas del tipo T-11213 de fábrica local (CEPE/CA09/27, 81, 121, 171 y 177) con bordes en general triangulares y poco desarrollados en vertical, espaldas curvadas verticales y asas de sección circular de gran tamaño colocadas (en su extremo superior) sobre la carena de los hombros (Fig. 11). Del mismo modo, otros bordes de apariencia algo más evolucionada podrían estar indicando la presencia de envases del T-11214/5, propios de las décadas finales del siglo V a.C. (CEPE/CA09/72 y 85) Asimismo, dentro de esta misma serie, se ha detectado la presencia 

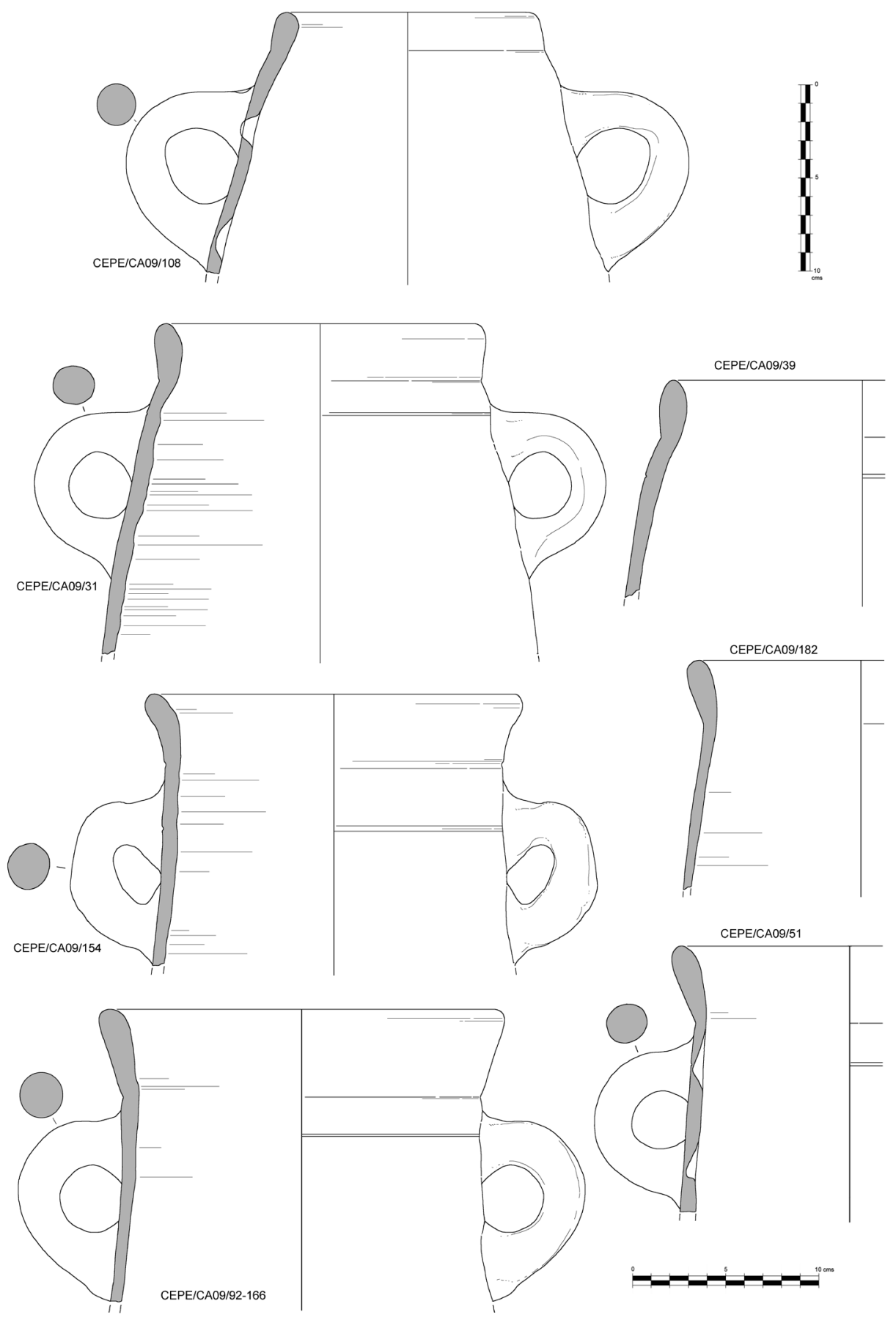

Figura 12: Envases anfóricos de fábrica gadirita encuadrables en versiones del tipo T-1323 y formas antiguas de la serie T-8211, procedentes de La Cepera.

de alguna importación en forma de individuos del tipo T-11216 (CEPE/CA09/163), quizá provenientes de la mitad mediterránea de la región del Estrecho o de la Mauritania septentrional (Ramon, 2004). A esta fase parecen pertenecer también algunos individuos de las versiones locales de T-1323 (CEPE/CA09/108) y versiones muy iniciales de las T-8211 (CEPE/CA09/31 y 39) (Fig. 12), que grosso modo podrían situarse en la transición de los siglos V-IV a.C. (Sáez Romero, 2014b), aunque resulta obvio que no es posible establecer conexiones claras entre ambos conjuntos de materiales en relación a su interpretación como posible parte de un cargamento único o su deposición paulatina como resultado del uso reiterado de este espacio como zona de tránsito o fondeadero estable.

Es muy posible que a estos horizontes tardoarcaicos haya que sumar también otros ítems (Fig. 13), como un posible ejemplar de tinaja de cuerpo acilindrado, borde proyectado al exterior y asas voluminosas similares a las de las ánforas coetáneas (CEPE/CA09/127), 

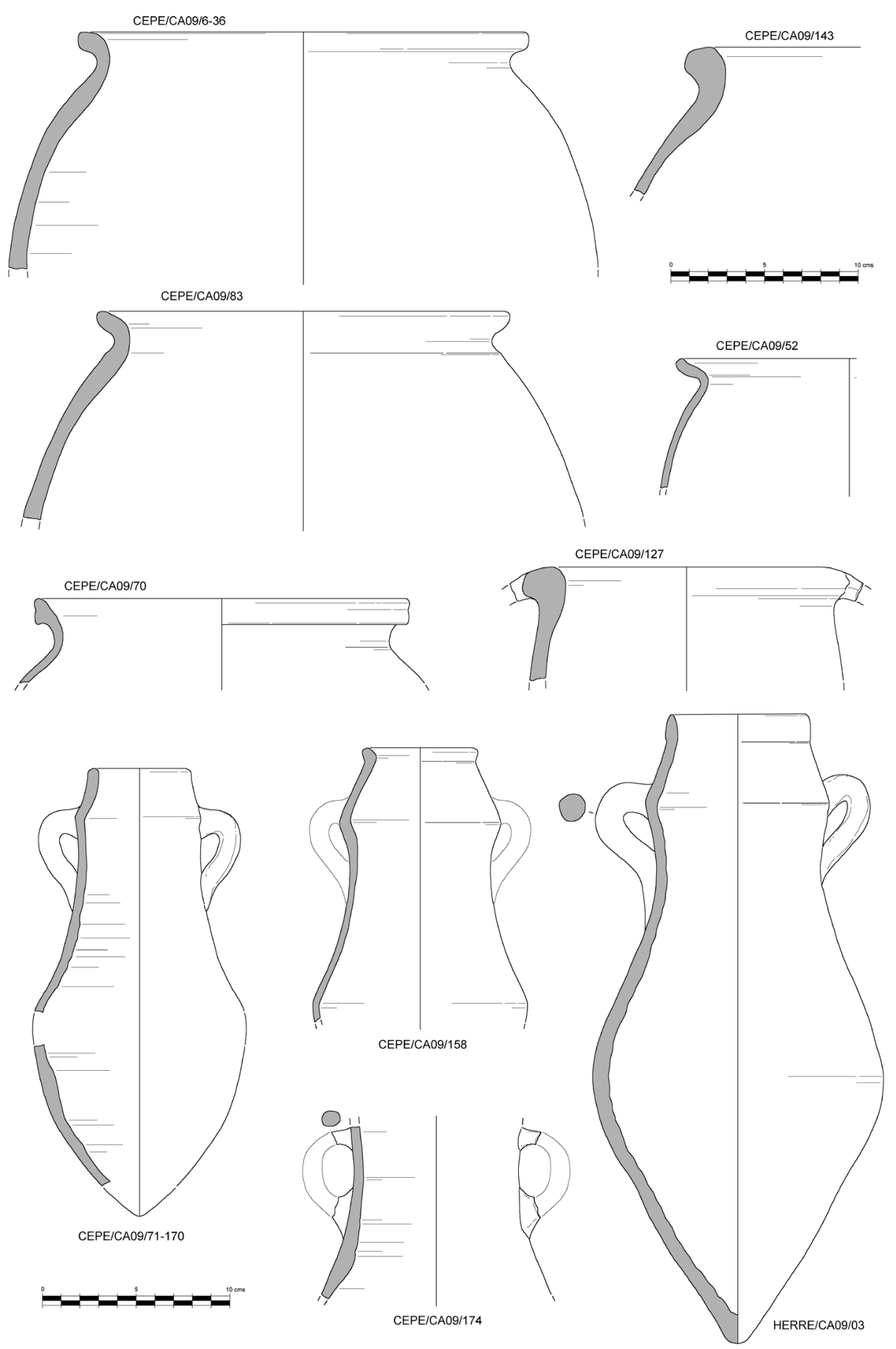

Figura 13: Materiales cerámicos no anfóricos de La Cepera y Laja Herrera: ollas de borde vuelto al exterior, posible tinaja anforoide y anforillas miniaturizadas.

similar a los individuos presentes en Canal del Sur y que encuentran sus referencias más evidentes en los tipos XIa2-3 de Camposoto (Ramon et alii, 2007, 91). Como ya se avanzó a propósito de los materiales de Canal del Sur, es posible que algunas de las ollas de pastas groseras y formas globulares con labios vueltos al exterior puedan pertenecer a este horizonte púnico (CEPE/CA09/06, 36, 38, 83 y 143), cuestión que no es posible dilucidar dada la falta de asociaciones contextuales directas pues estos perfiles sin cambios significativos parecen perdurar hasta momentos tardopúnicos (Sáez Romero, 2008).

Otros integrantes de la serie T-8211 permiten definir en base a sus tipologías la existencia de una frecuentación o uso de esta área de La Cepera a lo largo de los siglos IV-III a.C. (Figs. 12 y 14) En concreto, pueden distinguirse individuos de boca ancha y labios rectos ligeramente exvasados propios del siglo IV o el tramo inicial del III a.C. (CEPE/CA09/51, 92, 166, 154 y 182), pero la gran mayoría de los individuos 


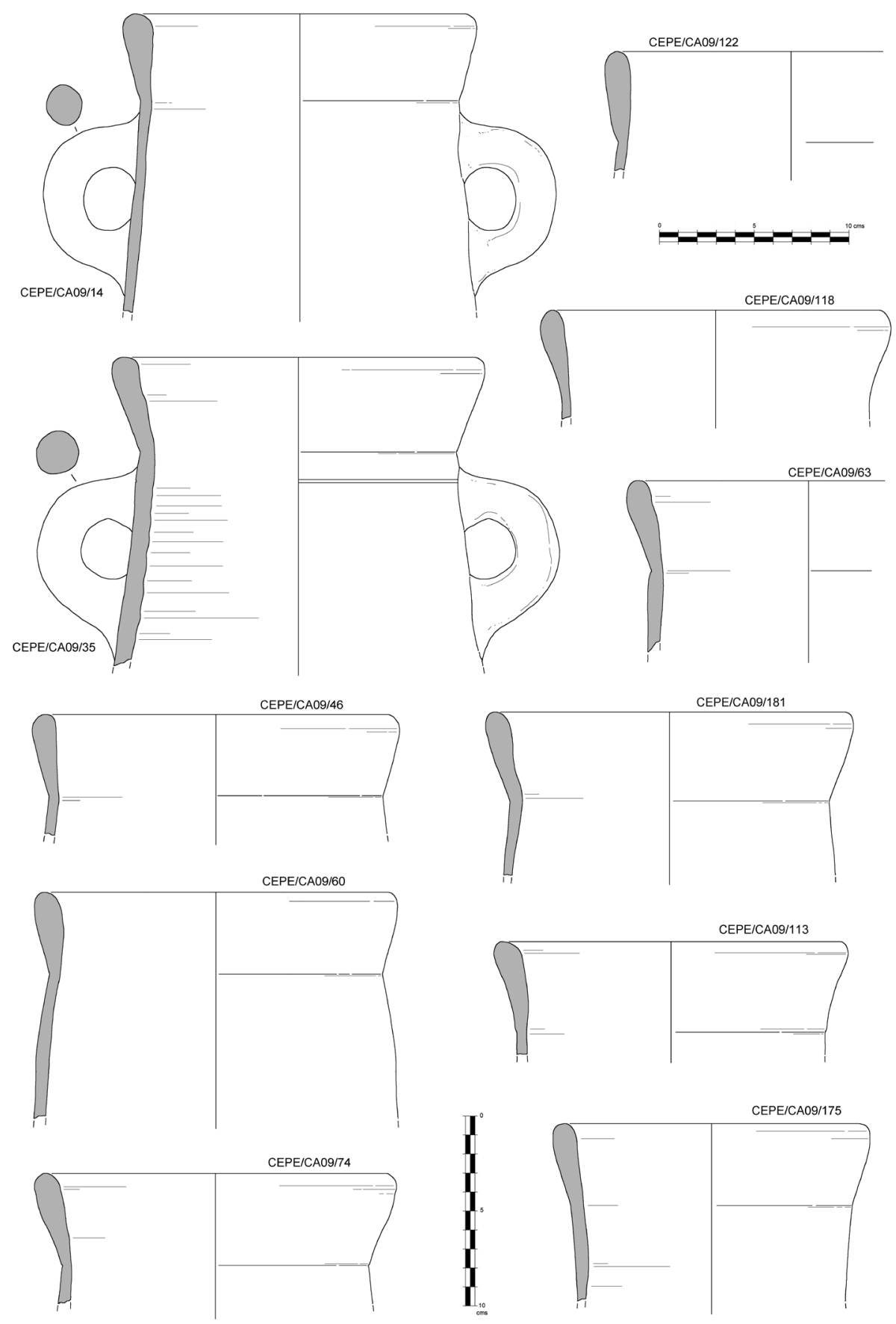

Figura 14: Ánforas del tipo T-8211 documentadas en La Cepera.

recuperados parece pertenecer ya a perfiles de menor diámetro y más simplificados en sus atributos ubicables en el transcurso del siglo III a.C. (CEPE/ CA09/14, 35, 46, 60, 63, 74, 113, 118, 122, 175 y 181) o quizá incluso en el II a.C. (CEPE/CA09/67 y 137) (Fig. 15). Junto a este abultado conjunto de T-8211, quizá formando en algún caso parte de un mismo depósito o cargamento, encontramos algunas T-12111/2 de tamaño diverso, carentes de la incisión externa sobre el labio - posiblemente por la acción de la erosión marina-, que presentan morfologías propias del siglo III a.C. o de inicios del II a.C. (CEPE/CA09/13, 61 y 76) (Fig. 11).

Además de esta nutrida representación de envases de transporte de uso netamente comercial cabe destacar la presencia en el conjunto de ítems fechables en la etapa púnica de otras piezas de menor tamaño de tipologías ampliamente conocidas en los registros subacuáticos del entorno de La Caleta. Entre ellas se incluyen un mínimo de tres individuos de diversa 

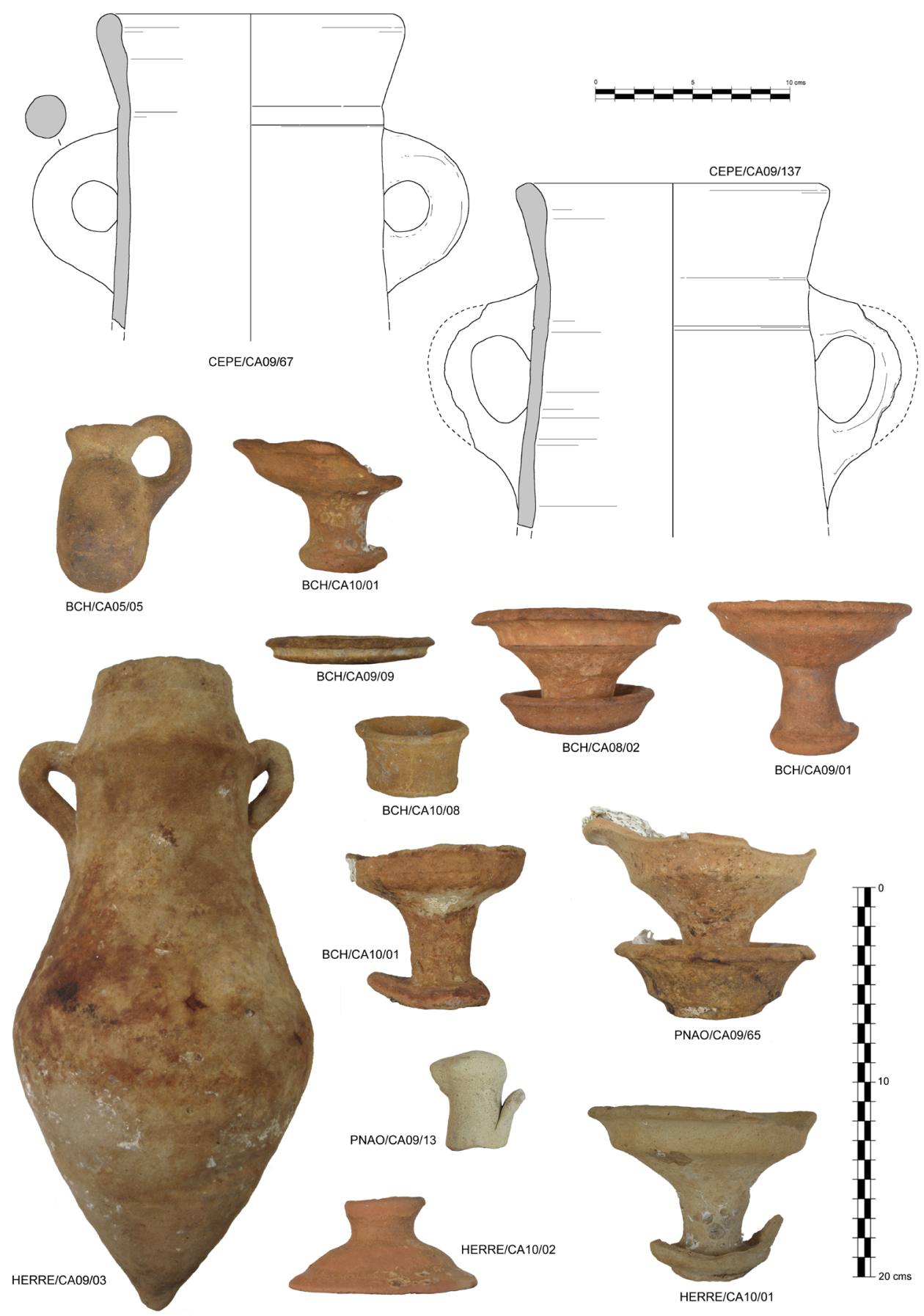

Figura 15: Ánforas del tipo T-8211 documentadas en La Cepera, y material de pequeño tamaño y diversa tipología procedente del mismo yacimiento y de Punta del Nao, Laja Herrera y Bajos de Chapitel.

tipología de las célebres anforillas miniaturizadas que versionan los envases locales del tipo T-11/T12 (Figs. 13 y 15) vinculados esencialmente al transporte salazonero (CEPE/CA09/71, 170, 158 y 174). Asimismo, es posible que en este difuso intervalo desarrollado entre los siglos V-III a.C. también puedan situarse algunas tinajas con o sin asas, de bocas anchas y cuerpos ovoides de notable capacidad (CEPE/ CA09/07 y 70), vinculadas a precedentes o versiones iniciales del grupo GDR-8.1.1 característico de la producción local púnica tardía (Sáez Romero, 2008). Finalmente, es posible que también de este lapso date alguna olla de tipo globular con labio vuelto al exterior, con paredes más finas que sus predecesoras y dotada de un reborde a modo de solero que sugiere el empleo de tapadera (CEPE/CA09/52), elemento propio de la helenización de estos repertorios locales de cocina y bien conocida entre los repertorios de talleres cerámicos insulares como Torre Alta o Luis Milena. 

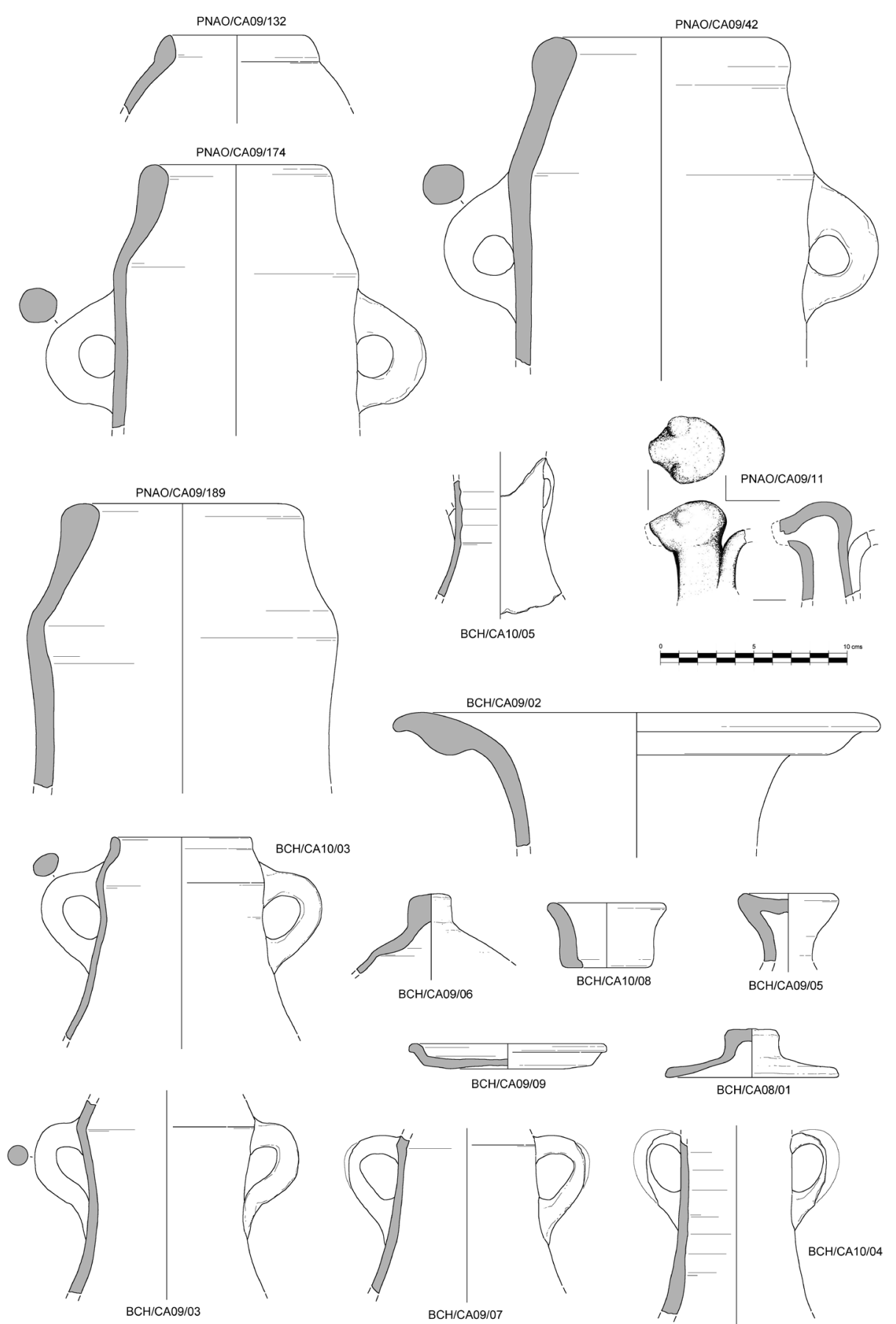

Figura 16: Materiales diversos hallados en Punta del Nao y Bajos de Chapitel: ánfora T-11213, envases del tipo T-12111 y T-7421, askos aviforme, anforillas miniaturizadas, carrete, platito y tapaderas.

\section{3. PUnTA Del NaO}

En cuanto al estudio de los materiales datados en una fase anterior al horizonte altoimperial, predominante en esta zona desde la perspectiva cuantitativa de entre los materiales procedentes de las actuaciones de 2008-2010, cabe señalar que éstos fueron escasos y se documentaron dispersos sin revelar concentraciones significativas o indicios de estructuras infrayacentes (Fig. 16). Los ítems más abundantes son por supuesto las ánforas, entre las cuales la de datación más antigua parece ser un ejemplar posiblemente local del grupo T-11213 (PNAO/CA09/132), con labio triangular y espalda notablemente curvada, características que parecen situar el ejemplar en el tramo central del siglo $\mathrm{V}$ a.C. A un horizonte púnico (en cualquier caso no posterior al siglo IV a.C.) podría también asociarse un ejemplar de quemaperfumes de doble cazoleta (PNAO/ CA09/65), similar a los documentados profusamente en el resto de localizaciones exploradas en 2008-2010, 
destacando en este caso por su buen estado de conservación (Fig. 15). Aunque como ya se avanzó se trata de elementos de compleja datación cuando carecen de una asociación contextual clara, en este caso sus características básicas ( $\sin$ rastros de engobado en rojo, cazoleta inferior de menor diámetro, carenas muy aristadas) parecen apuntar hacia un individuo fabricado en talleres de la propia bahía en época post-arcaica, mostrando muchas semejanzas con los perfiles de Camposoto (Ramon et alii, 2007, 90, fig. 160, tipo I1a1).

El resto de individuos anfóricos parece situarse en un arco cronológico mucho más tardío, destacando la presencia de tres T-12111 tardías de importación, cuyas pastas y tipologías denotan orígenes y momentos de deposición probablemente diferenciados (Fig. 16). Por una parte, un ejemplar con el labio notablemente engrosado al exterior y pequeñas asas colocadas por debajo del nivel de la carena de los hombros, definiendo un cono superior completamente acilindrado (PNAO/ CA09/42); por otra, un individuo aún más evolucionado con labio simple, espalda muy vertical y asas directamente sobre la pared del cono superior, completamente cilíndrico (PNAO/CA09/174); por último, otro ejemplar de labio simple con carena muy redondeada en el que no se conservaban las asas (PNAO/CA09/189). En todos los casos resulta complicado discernir el centro de producción de origen de estas ánforas, coincidentes tipológicamente con individuos del área de KuassLixus en la Mauritania atlántica (Kbiri Aloui, 2007) que se sitúan sobre todo entre los siglos III-II a.C., como sugieren los hallazgos estratificados de Lixus (Aranegui, 2001 y 2005; Aranegui y Hassini, 2010), pero también con producciones tardías de la costa malacitana (Marzoli, 2000). En cualquier caso, estas ánforas, como se ha visto en casos similares de Canal del Sur o La Cepera, testimonian la recepción en la bahía gaditana de productos envasados procedentes de otros focos del área del Estrecho, evidenciando no sólo el posible papel de gran centro consumidor de sus núcleos poblacionales (considerados en conjunto) sino también su rol como puerto redistribuidor de primera magnitud hacia las grandes rutas internacionales o hacia las capilarizadas rutas interiores o atlánticas (Sáez Romero, e.p.).

Un fragmento de askos aviforme (PNAO/ CA09/11), prototipo bien conocido en los ambientes funerarios gaditanos del siglo II e inicios del I a.C. (Muñoz, 1992; Sáez, 2006) (Figs. 15-16) completa esta imagen de los materiales de la transición a la etapa romano-republicana, y aporta un sugerente indicio adicional sobre la posible acción de erosión oceánica sobre los bajos del brazo de Santa Catalina y el que éstos hubiesen albergado en esos momentos alguna zona de enterramiento.

\section{4. LAJA HERRERA}

En buena medida los materiales de época prerromana recuperados en esta localización repiten en general el patrón descrito para las anteriores, testimoniando algunos de los momentos clave o de máxima intensidad de uso del puerto exterior gaditano. Los testimonios más antiguos corresponden a una posible T-10121 similar a las documentadas en La Cepera o Canal del Sur 5, en este caso representada por un borde triangular macizo y el inicio de la espalda quizá de momentos avanzados del siglo VII o del primer tercio del VI a.C. (Sáez e Higueras-Milena, e.p.). Probablemente ya a intervalos plenos del siglo $\mathrm{V}$ a.C. pueden atribuirse un borde triangular e inicio de la espalda de un ejemplar también local del tipo T-11213 (HERRE/CA09/07) (Fig. 17), pero también una tinaja biansada muy próxima al tipo XIa2 del taller de Camposoto (HERRE/CA09/16) y quizá un pithos de gran volumen con asas adheridas al borde y notablemente acanaladas en sentido longitudinal próximo al tipo CVa1 (Ramon et alii, 2007) aunque carente de vestigios de decoración polícroma (HERRE/CA09/14), acaso además de un fondo simple de una forma similar (HERRE/CA10/07).

Un significativo conjunto de evidencias de diverso tipo parece poder colocarse cronológicamente en un momento algo posterior, aunque desafortunadamente en la mayor parte de casos sea imposible precisar el momento de fabricación/deposición. No es el caso de un individuo identificable como un prototipo precursor a nivel local del tipo T-8211, identificado recientemente como una posible interpretación gadirita de las T-1323 ebusitanas de finales del siglo V a.C., y cuya asociación a la T-11213 anterior no puede excluirse (se trata del fragmento HERRE/CA09/12). La tipología propia de estos envases, objeto de atención en diversos trabajos recientes (Sáez Romero, 2014b), con una boca relativamente estrecha que define un cuerpo ovoide con asas fijadas en la zona alta bajo el nivel del labio (normalmente corto y apenas diferenciado) permite fijar esta cronología con pocas dudas, siendo este junto a los individuos de La Cepera y Canal del Sur 5 los primeros testimonios de su puesta en circulación por vía marítima, con destinos aún inciertos. Un ejemplar mucho más tardío de esta serie, con cuerpo acilindrado estrecho y boca conformada por labio alto y levemente exvasado (HERRE/CA09/10) testimonia la circulación de estas versiones finales de la familia en momento probablemente ya avanzados del siglo III a.C., fase en la cual el tipo T-8211 alcanza de nuevo una significativa expansión a nivel regional y atlántico.

Como en yacimientos tratados anteriormente, cabe situar en un difuso intervalo (entre la fase arcaica y, sobre todo, los siglos VI-III a.C.) otros elementos de fábrica local y pequeño porte que tradicionalmente han sido relacionados con actividades cultuales ofrecidos luego in situ a las aguas de La Caleta. En concreto, destaca la presencia de dos de las anforillas inspiradas en el perfil de las T-11/T12 regionales (HERRE/CA09/02 y 03; Figs. 13 y 17), en este caso una de ellas entera y la otra conservando casi la totalidad de la mitad superior, mostrando unos rasgos simplificados (borde indiferenciado, carena poco marcada) 

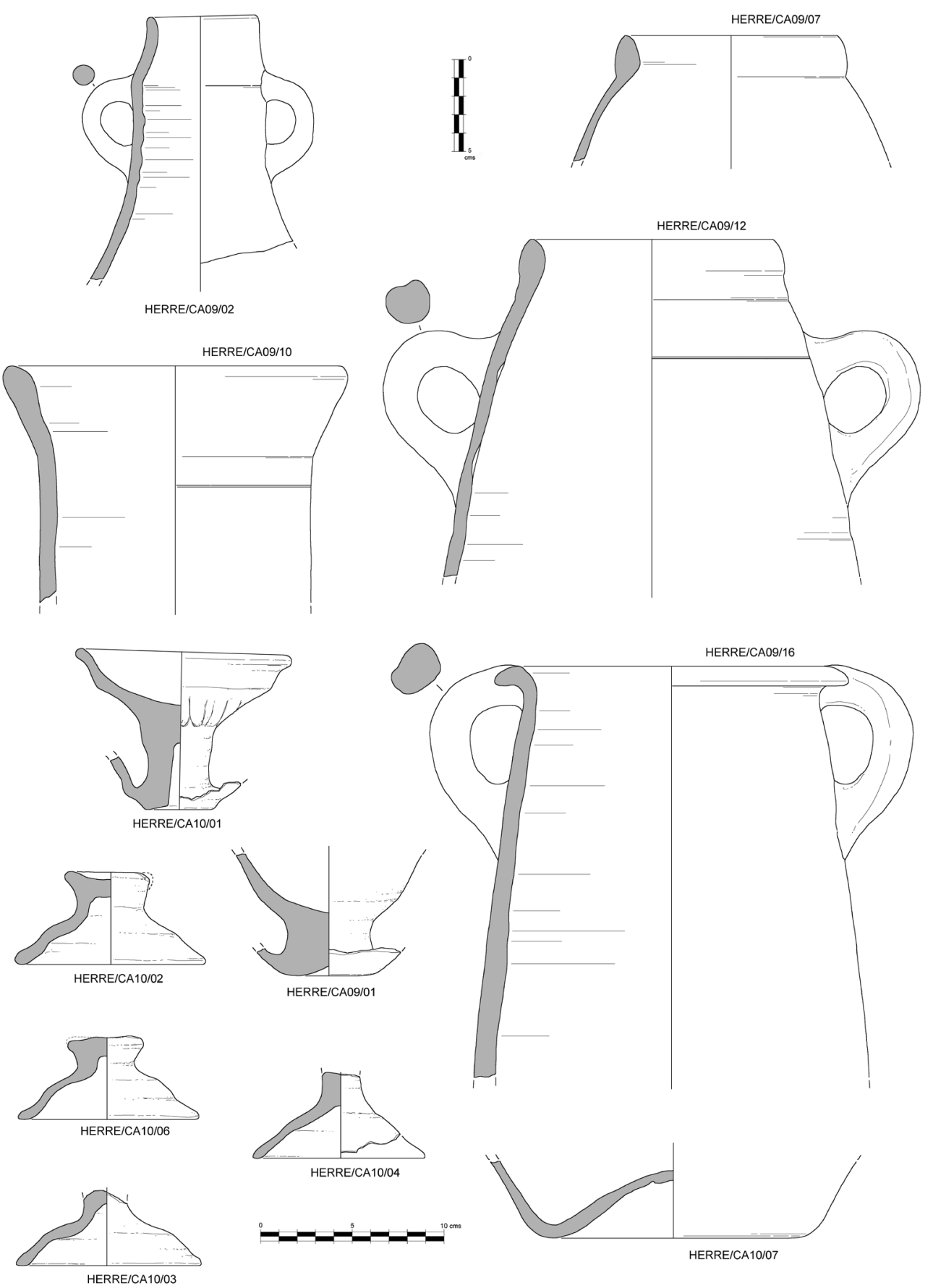

Figura 17: Materiales procedentes de Laja Herrera: ánforas T-11213, T-1323/T-8211, tinaja anforoide con posible fondo rehundido, anforilla en miniatura, pebeteros de doble cazoleta y tapaderas.

que permiten sospechar una cronología relativamente tardía de los individuos dentro de este lapso (con paralelos del siglo III a.C. en Doña Blanca o Puerto-19; Niveau, 1999; Gutiérrez, 2000).

A ella debemos unir dos quemaperfumes de doble cazoleta, ambos en malas condiciones de conservación, uno de ellos con la cazoleta inferior de menor diámetro, astil central hueco y cuenco superior con borde redondeado (HERRE/CA10/01) y otro mucho más tosco, con un astil corto y macizo y una cazoleta superior que se intuye bastante profunda (HERRE/ CA09/01). Es posible que estos quemaperfumes puedan estar relacionados con alguna de las cuatro tapaderitas comunes localizadas en el yacimiento, todas ellas repitiendo el mismo esquema de líneas simples, con bordes indiferenciados, galbo sinuoso y dotadas de pomos más o menos macizados o proyectados en vertical (HERRE/CA10/02, 03, 04 y 06), dos de ellas reversibles para su uso como pebetero. Se trata en todos los casos de materiales ampliamente conocidos en la 
zona, como se ha reiterado en la introducción de este trabajo y en los casos de La Cepera y Canal del Sur, sin que sea necesario por tanto insistir en las dificultades de atribución cronológica precisa de los mismos sin otras asociaciones contextuales.

\subsection{BAJO DE CHAPITEL}

En estas campañas el material recuperado en esta zona de Chapitel fue muy escaso, mostrando además una facies muy característica de este entorno de La Caleta que apenas incluyó evidencias del tráfico de productos envasados en ánforas (contrariamente a lo mostrado por actuaciones precedentes). De hecho, el único individuo identificado en el conjunto corresponde a un borde e inicio del cuello de un envase del tipo T-7421 de fábrica tunecina $(\mathrm{BCH} / \mathrm{CA} 09 / 02)$, frecuentes por otro lado en los registros materiales de la bahía tanto en contextos de consumo netos como productivos o funerarios (Niveau, 1999; Sáez Romero, 2008) normalmente de los últimos años del siglo III y sobre todo de la primera mitad o dos primeros tercios del II a.C. (Fig. 16).

El grueso del material corresponde a objetos en pasta común aparentemente local de tipos que normalmente han sido relacionados por la historiografía precedente con actividades cultuales realizadas en las aguas inmediatas a los santuarios ubicados también de manera virtual en estos extremos occidentales de la isla de Erytheia (Figs. 15-16). Destaca cuantitativamente la presencia de un mínimo de cinco individuos identificables con diferentes variantes formales de las ánforas miniaturizadas del grupo T-11/T-12, de entre las cuales una de ellas presenta una boca notoriamente más ancha y un perfil de cuerpo que puede intuirse corto y redondeado (BCH/CA10/03), al estilo de las jarras de espalda carenada producidas profusamente en los talleres locales -como Camposoto- desde al menos el pleno siglo V a.C. (Ramon et alii, 2007, tipos CIIIa1 y CIIIb1). El resto de fragmentos, en diverso grado de conservación (BCH/CA09/03 y 07; BCH/ CA10/04 y 05), corresponden a la zona del cono superior, incluyendo en algunas ocasiones la carena de los hombros y las asas, definiendo diferentes perfiles que recuerdan vivamente los ejemplares ya rescatados de otras áreas de La Caleta (Muñoz, 1993), siendo especialmente significativa la presencia de una versión de tamaño muy reducido (BCH/CA10/05) bastante afectado por la erosión marina. Como ya se ha discutido en la introducción historiográfica y en el apartado dedicado a los hallazgos de La Cepera o Canal del Sur, la cronología de este tipo de anforillas resulta muy compleja únicamente en base a sus afinidades tipológicas con los modelos de referencia, dada su presencia en contextos terrestres datados incluso hasta finales del siglo III a.C. (Niveau, 1999; Gutiérrez, 2000).

Otro tanto puede reiterarse en relación a la presencia de quemaperfumes de doble cazoleta en esta zona de Chapitel, ítems también tremendamente frecuentes en todas las zonas arqueológicas del entorno de La Caleta (Pérez Hormaeche, 1990; Muñoz, 1993), y de los cuales ya se ha tratado en trabajos anteriores (Sáez e Higueras-Milena, e.p.). En este caso se trata de tres individuos en relativo buen estado de conservación, que muestran sin embargo perfiles diferenciados aunque con fábricas aparentemente locales (Fig. 15). Por una parte, un ejemplar con astil desarrollado y hueco con perforación practicada en la base pre-cocción, dejando una pequeña rebaba interior (BCH/CA09/01); otro con un astil mucho más grueso y corto, con apenas separación entre ambas cazoletas, poco profundas y carenadas, también con un hueco central pero mucho más fino (BCH/CA08/02); y un ejemplar de líneas más toscas, alto y con un vástago central sólo perforado hasta la mitad de su desarrollo, con una cazoleta superior profunda y una inferior apenas insinuada por un galbo carente de carena y con escaso desarrollo vertical (BCH/CA10/01). Es posible que en conexión funcional con estos quemaperfumes se encuentran algunas tapaderas de diverso porte documentadas en el mismo bajo, algunas de líneas muy simples con pomo hueco poco desarrollado (BCH/CA08/01) o macizo (BCH/CA09/06) junto a otras de mayor diámetro y poco igualmente hueco pero mucho más prominente (BCH/CA09/05), o incluso también un pequeño platito similar al recuperado en Canal del Sur 5 (BCH/ CA09/09), que pudo actuar indistintamente de contenedor para quemar las sustancias perfumadas o como tapadera ocasional de alguno de los ejemplares de doble cazoleta.

Por último, cabe hacer mención a la presencia de un pequeño carrete o soporte acilindrado (Fig.15, $\mathrm{BCH} / \mathrm{CA}-10 / 08)$, de escaso diámetro y desarrollo vertical, cuya pasta sugiere un posible origen en talleres locales. Se trata de una pieza fabricada a torno, con bordes redondeados, aunque en uno de sus extremos presenta leves rebabas al interior del cilindro que denotan un acabado tosco. El extremo contrario muestra un cierto exvasamiento, quizá evidenciando una adecuación para el ajuste como apoyo de algún tipo de recipiente de fondo ojival. La función de este ítem en este contexto subacuático de Chapitel suscita desde luego no pocas dudas, pues la falta de una asociación directa a otros elementos rescatados en esta zona no permite determinar si pudo contribuir a sostener por ejemplo a las pequeñas anforillas miniaturizadas o si pudo ponerse en relación con ampollas, juglets (Fig. $\left.15, \mathrm{BCH} / \mathrm{CA} 05 / 05^{7}\right) \mathrm{u}$ otras formas apropiadas para el apoyo sobre superficies planas.

\footnotetext{
7. Los autores agradecen a Josefa Martí Solano (IAPH-CAS) la autorización para incluir esta pieza hallada en la campaña inédita desarrollada en el año 2005 como referencia de este tipo de jarritas, frecuentes entre los repertorios prerromanos documentados en aguas de La Caleta (algo ya destacado en Muñoz, 1993).
} 
La producción local de este tipo de pequeños carretes no se encuentra por ahora identificada y sistematizada tal y como sería deseable, y apenas en algunos centros alfareros ha sido posible documentar su presencia entre las manufacturas locales, caso por ejemplo de algún ejemplo del siglo V a.C. de Camposoto (Ramon et alii, 2007, 88, tipo FIa2) o de algunos contextos del siglo II a.C. de Torre Alta (Sáez et alii, 2016b, en este caso asociados a la separación de los vasos de barniz rojo durante el proceso de cocción). En este caso que ahora nos ocupa parece que la funcionalidad del carrete no debió estar vinculada con actividades alfareras o industriales, sino más bien como sostén de algún tipo de vaso que no es posible determinar, aunque habrá que seguir profundizando en el análisis y rastreo de este tipo de elementos cerámicos en otros contextos gaditanos para definir con más seguridad estos parámetros de uso.

\section{CONCLUSIONES Y PROPUESTAS DE FUTURO}

El estudio de los testimonios materiales aportados por las inmersiones desarrolladas en el ámbito del proyecto de 2008-2010 debe quedar contextualizado en el ámbito de una actividad que en su momento se planteó como paso inicial de un programa de actuaciones más ambicioso y cuyos objetivos esenciales eran muy diversos. Entre ellos, la aplicación experimental de las técnicas geofísicas en el análisis de yacimientos sumergidos; la determinación de la utilidad de los diferentes sistemas para la localización de éstos a partir de un case study significativo y relativamente amplio $\mathrm{y}$ con diversidad de tipos de fondos; y finalmente tratar de conjugar estos datos con la ya conocida presencia de restos arqueológicos de distinta naturaleza en la superficie de buena parte del espacio elegido para el desarrollo del proyecto, incluyendo yacimientos de especial relevancia para la historia de la bahía gaditana y de la región del Estrecho de Gibraltar.

Los objetivos que se perseguían con el desarrollo de este proyecto iban encaminados a la consecución de diferentes mejoras en tres líneas principales de trabajo, vinculadas a la obtención de datos geofísicos y batimétricos, a la catalogación de nuevos yacimientos y su inventario en los listados de protección vigentes y a la evaluación de nuevas y antiguas evidencias arqueológicas procedentes de esta zona noroeste de la costa de la isla gaditana. En este sentido, debemos señalar que la campaña de prospección geofísica ha permitido realizar una primera caracterización de la diversidad de los tipos de fondos de la zona objeto de estudio (arena, cascajo, limos, rocas, etc.), registrándose gráficamente los mismos y la respuesta con ítems arqueológicos muy diversos (cerámicas, metales, molinos de piedra, etc.). Asimismo, varios nuevos yacimientos de diversas épocas han podido ser catalogados e inicialmente explorados, lo que augura en un futuro cercano una sustancial mejora en el conocimiento general de la dinámica geoarqueológica de la zona y de sus componentes materiales.

De este modo, en relación a las conclusiones que ahora podemos plantear parece conveniente recalcar que no se proyectaba llevar a cabo una investigación completa o definitiva del área objeto de estudio, inabarcable por su amplitud, condiciones de visibilidad y riqueza arqueológica. Por ello, al margen de los resultados históricos concretos, algo que ha quedado evidenciado es la necesidad de desarrollar nuevos proyectos de investigación ${ }^{8}$ sistemática en esta zona que permitan interpretar el inmenso volumen de datos sobre historia marítima, económica, cultual, geoarqueología, etc, que se encuentran ocultos en las aguas del noroeste gaditano, y que a su vez que permitan localizar nuevos vestigios, documentarlos con las metodologías científicas más actualizadas y establecer medidas de protección (aspecto básico puesto en evidencia por el conocido potencial arqueológico de la zona y el alto riesgo de expolio, avalado desafortunadamente por una larga trayectoria en la segunda mitad del siglo $\mathrm{XX)}$.

Tornando al objeto central de estas páginas, es en la parcela del estudio de los materiales procedentes de estos yacimientos caleteros en una de las que más se ha avanzado gracias a estos trabajos de 2008-2010 (sumando nueva documentación al catálogo de materiales prerromanos y romanos ya conocidos) y la posibilidad de cotejar esta documentación con una creciente información estratificada procedente de yacimientos habitacionales, funerarios e industriales diseminados a todo lo largo y ancho de la bahía. Antes de plantear una interpretación panorámica global de los hallazgos datados entre los siglos VI-III a.C. desgranados en el apartado precedente merece la pena detenerse brevemente en recapitular sobre la problemática específica de cada una de las cinco zonas objeto de atención, repasando la composición de sus conjuntos materiales y su potencial aportación futura al análisis conjunto de la zona de La Caleta en época púnica.

En primer lugar, en el caso de las dos localizaciones de Canal del Sur resulta obvia la necesidad de continuar con la prospección geofísica de todo este entorno, antigua canal de entrada entre la costa y el cordón de bajos - posibles islotes en la Antigüedad- de La Cepera, Chapitel, Laja Herrera, Los Cochinos, Las Puercas, etc., con una posible área de fondeo en su centro al resguardo del brazo de Santa Catalina-Punta del Nao. Además, la notable presencia de materiales sugiere la necesidad de llevar a cabo una prospección visual abarcando un área más amplia, revisando en detalle

8. Se encuentra en fase de preparación un proyecto específico para el estudio de los «objetos de tipo cultual» documentados en La Caleta, con el objetivo fundamental de sistematizar la información disponible y actualizar criterios de interpretación y datación. 
las anomalías detectadas en la prospección geofísica, y también la realización de sondeos estratigráficos que confirmen la potencia de las diversas localizaciones del yacimiento y la virtual presencia de restos de maderamen que puedan respaldar la existencia de pecios.

Los nuevos hallazgos de Canal del Sur vienen a llenar de contenido afirmaciones derivadas de los primeros contactos de carácter científico con esta zona de La Caleta a cargo de Olga Vallespín, quien afirmaba ya hace varias décadas que «El Canal del Sur es zona muy interesante para realizar hallazgos arqueológicos. Sobre ella hemos tenido referencias orales sobre restos de cañones de bronce y otro tipo de materiales más interesantes para nosotros, como terracotas púnicas $y$ restos de ánforas, etc. Sin embargo, los resultados de nuestros rastreos fueron totalmente nulos. Hay que decir que este fondo es muy turbio y es difícil localizar los pecios» (Vallespín, 1985, 69). Resulta por tanto indudable que, a la luz de las nuevas evidencias y pese a la puntualidad de las actuaciones acometidas, la zona de Canal del Sur deberá ser uno de los escenarios preferentes en futuras fases de intervención que habrán de hacer posible definir aspectos que las prospecciones y sondeos de 2008-2010 no han permitido aclarar de forma definitiva. Entre ellas, como ya dijimos si los horizontes materiales definidos a partir del estudio de materiales y de las concentraciones documentadas en contexto estratigráfico corresponden a pecios superpuestos o próximos entre sí (como parece plausible, al menos para parte del material fenicio-púnico), o por el contrario a otras vías de formación de los depósitos arqueológicos (vuelcos parciales, objetos arrojados intencionalmente de forma periódica, etc.).

Para el caso de La Cepera, los abundantes materiales correspondientes tanto a época fenicio-púnica como a momentos romano-republicanos aconsejan el desarrollo futuro de un programa de actuación similar al de Canal del Sur, a lo que habría que añadir el estudio de la dinámica marina de la zona (incidencia de corrientes, temporales, tsunamis, etc.) que permitan explicar científicamente la presencia de restos documentados encajados bajo grandes rocas. La interpretación que damos al conjunto de evidencias materiales rescatadas en este sector, sin descartar la posibilidad de que algunos de los grupos detectados correspondan a naufragios sobre zona de rocas o en su entorno cercano, es que podría tratarse de una zona de fondeo con amplia perduración en uso, en el que el topónimo derivaría precisamente de esta persistencia en su función como zona de anclaje exterior al canal portuario principal y a la consiguiente acumulación de restos de cepos y anclas. Es decir, un punto geoestratégico frecuentado por los buques que arribaban o partían del puerto gaditano durante más de un milenio, extremo occidental de una posible área protegida de los rigores directos del Atlántico en cuyo centro se encontraría el Canal del Sur.

Los materiales analizados procedentes de las campañas de 2008-2010 parecen refrendar esta extensa diacronía de la frecuentación de La Cepera, pues como se ha visto integran desde ánforas fenicias arcaicas hasta envases romanos, con un momento de uso intenso para la etapa púnica denunciado por las ánforas T-11210, T-12111 o T-8211 y las anforillas en miniatura (siglos V-III a.C.).

La Punta del Nao constituye uno de los puntos más intensamente expoliados del entorno de La Caleta, y que han proporcionado algunos de los hallazgos más significativos en relación a la fase fenicio-púnica de uso de este balcón marítimo de Gadir ${ }^{9}$. Al igual que en los casos anteriores, y aún cuando las actuaciones de 2008-2010 permitieron recuperar sobre todo material romano en dos puntos de alta concentración de materiales, resulta evidente que el yacimiento deberá ser sometido en siguientes fases de intervención a una nueva prospección geofísica de detalle complementada con un reconocimiento visual de las anomalías y el planteamiento de sondeos estratigráficos en los puntos seleccionados en la fase de prospección. La prospección geofísica permitió identificar en la zona un total de 37 anomalías, señalando en el extremo más occidental una acumulación de tres anomalías de sísmica (SIS 315, SIS 316 y SIS 318) y una de magnetismo (MAG 3-1). Se realizó una sola prospección circular en torno a estos puntos en concreto, pero no se localizó ningún material debido a la escasa visibilidad, por lo que está pendiente el rastreo de la zona en futuras fases de intervención en momentos con vientos y corrientes más propicios que permitan completar la verificación de la naturaleza de las anomalías.

La documentación recuperada de las aguas del entorno de la Punta del Nao en las campañas de 2008 a 2010 referida a los horizontes prerromanos no permite desafortunadamente la formulación de hipótesis de gran envergadura sobre la evolución de este emplazamiento respecto de la erosión marina o de su interpretación funcional histórica. Como se ha desgranado en el examen de los materiales y también es claramente perceptible en testimonios anteriormente rescatados de este ambiente subacuático costero (incluyendo numeroso material de pequeño tamaño de «tipo cultual», cabe plantear una posible doble vía para la formación de los depósitos arqueológicos documentados. Es decir, por una parte, elementos procedentes de pecios o del trasiego/fondeo de naves, de lo cual podrían ser testimonio especialmente las

9. No en vano, algunos de los primeros testimonios de la recuperación de material subacuático del área de La Caleta provienen de actividades desarrolladas en esta zona, como se reseña en este pasaje: «En el presente año de 1884, (...), en el sitio denominado Punta del Nao, próximo al Castillo de San Sebastián, y a algunas brazas de profundidad se encontraron bastantes ánforas que alli en gran número se hallaban reunidas. Por desgracia pocas salieron ilesas, habiéndolas sacado los pobres que a ello se dedicaron, como mejor pudieron. Hoy obran en poder de algunos particulares» (Vera y Vera, 1887, 121). 
ánforas de transporte de época púnica, tardopúnica y romana, tanto locales como importadas; y por otra, elementos que podrían provenir tanto de los efectos de la erosión marina de este sector (enterramientos o depósitos votivos ligados al culto de Astarté) como de la deposición directamente en estas aguas de ítems vinculados a ofrendas de entrada/salida o ceremoniales como las «procesiones marítimas» que se ha supuesto podrían haberse celebrado en este entorno de los templos septentrionales de Gadir (siendo los elementos más característicos los quemaperfumes, terracotas, anforillas, etc.). En cualquier caso, estas opciones quedan necesariamente abiertas en tanto los trabajos de prospección intensiva y sondeo no tengan continuidad en la zona.

Por último, en el caso de los Bajos de Chapitel y de Laja Herrera parece evidente la necesidad de continuar en la zona con las prospecciones geofísicas, revisando las anomalías mediante reconocimiento visual y abarcando un área más amplia del yacimiento. Los datos disponibles de estos bajos con anterioridad a los trabajos de 2008-2010 (Rodríguez y Martí, 2001; Martí, 2010) ya sugerían la presencia de material de datación fenicio-púnica abundante, aunque hay que puntualizar que se trata de fragmentos muy rodados comparados con los materiales estudiados en la presente campañatanto anfóricos como de tipologías/funcionalidades diversas. Por ello la escasez de la muestra analizada en estas páginas debe ser entendida como resultado de la puntualidad de las actuaciones en esta área y no de una inexistencia de frecuentación marítima en este punto durante los siglos VI-III a.C.

$\mathrm{Si}$ ascendemos hacia una mirada de conjunto de los resultados, los testimonios analizados permiten defender de nuevo la hipótesis de que el canal de La Caleta y sus bajos aledaños debieron ser un área portuaria de primer orden para el asentamiento de Gadir. Aunque no se conocen restos de infraestructuras construidas con finalidad portuaria, no cabe duda de que el canal constituido por el paleocauce del Guadalete debió convertirse en epicentro de estas actividades, si bien las recientes actividades de 2008-2010 ponen de relieve que la zona de fondeo distribuida alrededor de Canal del Sur, protegida por un significativo cordón de islotes al oeste, norte y este, debió haber jugado también un papel fundamental en la dinámica de uso de este reborde marítimo gadirita. Estos usos portuarios además debieron tener desde época fenicia una íntima conexión con la sacralidad atribuida a los extremos occidentales de las islas a través de santuarios ubicados en cada uno de los brazos del canal principal, vinculados con Kronos y Astarté. Es posible que al menos parte de los objetos de pequeño porte rescatados de esta agua tenga una relación directa con estos espacios sacralizados (que eran a su vez hitos para la navegación), aunque no está claro el que se trate de ítems arrojados intencionalmente tras ceremonias o que puedan provenir de otros orígenes como depósitos votivos arrasados por la erosión oceánica.
Esta indisoluble relación entre puertos, navegabilidad, comercio y áreas sacras no es precisamente algo desconocido en el mundo fenicio colonial, y en el caso de La Caleta ha sido puesta de manifiesto también para la etapa romana en relación a la posible existencia de un faro en el extremo occidental del brazo de San Sebastián (Bernal, 2009 y 2012). A modo de hipótesis, y del mismo modo que ya se propuso para el caso del santuario de Melqart en el extremo opuesto de la isla de Kotinoussa (Sáez Romero, 2009; 2014a), es posible así especular con la opción de que en época púnica o tardopúnica pudiese haberse erigido en esta zona del actual islote de San Sebastián un edificio de tipo tower temple (tipología bien conocida en ámbito fenicio oriental; Frost, 2002) que hubiese podido cumplir ambas funciones como área sacra y faro, constituyendo un precedente de las infraestructuras de época romana.

Uno de los aspectos generales que los materiales púnicos ahora analizados ponen de relieve es la destacada intensidad del tráfico marítimo generado por Gadir y su bahía en esta etapa histórica, pues los testimonios analizados del trasiego comercial de productos envasados en ánforas permiten aproximarnos no solo a la emisión, sino también a interesantes indicios de la recepción de importaciones que habrían sido objeto de consumo en la propia bahía o de redistribución hacia terceros destinos. Entre estas importaciones sobre todo destacar la presencia de ánforas de los grupos T-11210 y T-12111 de fabricación regional, procedentes probablemente de otros focos portuarios del área del Estrecho, lo que denota la existencia de redes comerciales de rango regional que podrían haber tenido el puerto gadirita como nodo principal de conexión con las rutas de rango internacional hacia el Mediterráneo central y oriental (aspecto extensible a la Pellicer D de fábrica turdetana). En todo caso, como en fases anteriores de la investigación, el análisis del material ha permitido constatar la presencia abrumadora de ítems con pastas que denuncian su producción en talleres de la propia bahía, tanto en lo referido a envases de transporte como otros objetos de menor tamaño.

Respecto a estos últimos, el repertorio detectado en las cinco localizaciones exploradas en 2008-2010 viene a refrendar en líneas generales la tendencia ya conocida por hallazgos anteriores, constatando la abundancia de pequeñas anforillas que reproducen los perfiles de las T-11210 o T-12110, los quemaperfumes de doble cazoleta con tapadera y dipper juglets (éstos, de cronología arcaica), a lo que debemos añadir ahora un askos aviforme, pequeños platillos y carretes acilindrados. Materiales que en general han sido interpretados como de uso cultual o votivo, y cuyo origen concreto no es posible determinar ahora tampoco en base a estos nuevos ejemplares dado que podrían provenir tanto de deposiciones rituales intencionales o limpiezas periódicas, como corresponder con residuos de una frecuentación marítima de la zona, naufragios de pecios que participaban en algún ritual o que abastecieran a la zona sacra, o tratarse de piezas que han 
acabado formando parte de los fondos subacuáticos de la zona debido a la erosión de estratos y estructuras existentes en época fenicio-púnica en los actuales bajos o en los brazos rocosos de La Caleta y que se han dispersado por los fondos debido a la dinámica marina (un desarrollo más amplio de la propuesta en Sáez e Higueras-Milena, e.p.).

Respecto a los envases anfóricos de fábrica local documentados en estas recientes prospecciones se constata en líneas generales la presencia reiterativa de tipos ya detectados en anteriores actuaciones (Vallespín, 1985; Alonso et alii, 1991; Muñoz, 1993; Martí, 2010), que en cualquier caso constituyen parte de las series masivamente fabricadas, consumidas y exportadas desde la bahía gaditana en la época púnica. No sorprende por ello la presencia de un buen número de ejemplares de T-11213, T-12111 o T-8211, formas que fueron fabricadas por millares en los alfares de la bahía y que debieron constituir una gran parte del volumen total de los fletes emitidos desde este foco portuario entre los siglos V-III a.C. Desafortunadamente, como ya se expuso en apartados previos, el carácter disperso del material y la falta de evidencias contextuales acerca de pecios no permite una asociación de estos materiales en naufragios u horizontes concretos, aunque sea posible ver en los conjuntos más nutridos posibles conexiones tipológicas basadas en los datos estratigráficos de las alfarerías gadiritas insulares.

Sin embargo, estos nuevos datos arqueológicos sí aportan dos sugerentes novedades en este capítulo referido a los envases de transporte: por una parte, la constatación de un notable número de individuos identificables como interpretaciones locales del tipo $\mathrm{T}-1323$ y de individuos muy iniciales del tipo T-8211, permitiendo por primera vez plantear la existencia de los primeros y establecer la hipótesis de un nexo entre ambas formas, siendo las T-1323 gadiritas el origen hacia el final del siglo $\mathrm{V}$ a.C. de la existosa serie $\mathrm{T}-8211$; y en segundo lugar, la detección de la posible circulación de envases no estrictamente anfóricos pero con capacidad para almacenar y ser transportados, como las tinajas biansadas de cuerpo acilindrado (¿y fondo plano?) que en diversas variantes parecen basarse en el esquema de los tipos Camposoto XIa23 o XIb3-4 (Ramon et alii, 2007, 90-91, figs. 160161). Esta última novedad resulta de interés no sólo por advertir sobre el hecho de que estos contenedores debieron participar del tráfico marítimo comercial gadirita, sino que además refuerzan la hipótesis de que estas series de tinajas podrían constituir un precedente remoto de series anfóricas cristalizadas formalmente durante el siglo III a.C., caso de las anforillas T-9111 que tanto éxito alcanzarían durante el siglo II a.C. Pequeños pasos en la definición de las características de las series anfóricas púnico-gaditanas y en el funcionamiento de los mecanismos de su distribución marítima, uno de los aspectos por ahora peor conocidos a pesar de su enorme impacto en la economía de la bahía prerromana.
Esta aportación centrada en los nuevos testimonios de época púnica, así como otras recientes acerca de otros conjuntos de diversa cronología y origen procedentes del área de La Caleta (Sáez et alii, 2016a; Sáez e Higueras-Milena, e.p.; González et alii, e.p.) deben enmarcarse en un momento general de revitalización de las investigaciones en la zona y, en general, de impulso de la arqueología marítima y subacuática de la bahía gaditana. A partir de estos primeros resultados metodológicos e histórico-arqueológicos consideramos que pueden formularse finalmente algunas propuestas o líneas futuras de actuación, algunas ya recurrentemente citadas a lo largo del trabajo. Por una parte, continuar y potenciar el estudio o re-estudio de colecciones o hallazgos inéditos o sólo parcialmente publicados, con especial atención sobre los abundantes registros anfóricos y a los numerosos ítems interpretados como objetos de culto; por otro, la necesidad de profundizar en los análisis geoarqueológicos y sobre todo en un trabajo más coordinado e interdisciplinar que pudiese dar origen a una "hipótesis de consenso» sobre la cual comenzar a situar y analizar los hallazgos arqueológicos diseminados por los diversos bajos de La Caleta; finalmente, el planteamiento de actuaciones arqueológicas amplias y sistemáticas en las zonas de mayor interés y chequeo de noticias antiguas en puntos de gran potencial para albergar yacimientos de peso.

\author{
Prof. Dr. Antonio M. Sáez Romero \\ Departamento de Prehistoria y Arqueología \\ Facultad de Geografía e Historia \\ Universidad de Sevilla \\ Calle de Doña María de Padilla s/n \\ 41004 Sevilla \\ asaez1@us.es \\ Aurora Higueras-Milena Castellano \\ Centro de Arqueología Subacuática IAPH \\ Balneario de la Palma. Duque de Nájera 3 \\ 11004 Cádiz \\ aurora.h.castellano@juntadeandalucia.es
}

\section{BIBLIOGRAFÍA}

ACQUARO, E., 1999: «La ceramica di Tharros in età fenicia e punica: documenti e prime valutazioni», en A. González Prats (ed.), La cerámica fenicia en Occidente: centros de producción y áreas de comercio, Actas del I Seminario Internacional sobre Temas Fenicios (Guardamar del Segura, 21-24 de noviembre de 1997), 13-40, Alicante.

ALONSO, C., 1991: «Informe de la campaña de prospecciones subacuáticas en la zona noroeste de la Playa de La Caleta (Cádiz)», Anuario Arqueológico de Andalucía/1989, vol. II, 329-330.

ALONSO, C., FLORIDO, C. y MUÑOZ, A. 1991: «Aproximación a la tipología anfórica de la Punta del Nao (Cádiz, España)», Atti del II Congresso Internazionale di Studi Fenici e Punici, vol. II, 601-616, Roma. 
ALONSO, C., GALLARDO, M., GARCÍA, C., PUEBLA, J. y ZAMBRANO, L.C., 1999: «Proyectos de tutela del Patrimonio Arqueológico Subacuático realizados por el Centro de Arqueología Subacuática», PH Boletín, 26, 130-137.

ALONSO, C., GRACIA, F. J. y BENAVENTE, J., 2009: «Evolución histórica de la línea de costa en el sector meridional de la Bahía de Cádiz», Revista Atlántica-Mediterránea de Prehistoria y Arqueología Social, 11, 13-37.

ÁLVAREZ ROJAS, A., 1992: «Sobre la localización del Cádiz fenicio», Boletín del Museo de Cádiz, V, 17-30.

ÁLVAREZ ROJAS, A., 1997: «¿Auletris gaditana? Notas sobre una figura en terracota del Museo de Cádiz», Boletín del Museo de Cádiz, 7, 107-113.

ALZAGA, M., MARTÍ, J., NAVARRO, M. y RODRÍGUEZ, N., 1999: «Documentación y análisis del riesgo antrópico del Patrimonio Arqueológico subacuático de Andalucía», PH Boletín, 26, 122-129.

ARANEGUI, C. (dir.), 2001: Lixus. Colonia fenicia y ciudad púnico-mauritana. Anotaciones sobre su ocupación medieval, Saguntum-extra 4, Valencia.

ARANEGUI, C. (dir.), 2005: Lixus-2 Ladera Sur. Excavaciones arqueológicas marroco-españolas en la colonia fenicia. Campañas 2000-2003, Saguntum Extra-6, Valencia.

ARANEGUI, C. y HASSINI, H. (eds.), 2010: Lixus-3. Área suroeste del sector monumental (Cámaras Montalbán) 2005-2009, Saguntum-Extra 8, Valencia.

ARTEAGA, O. y SCHULZ, H. D. (eds.), 2008: «Geoarqueología y proceso histórico en la Bahía de Cádiz», Revista Atlántica-Mediterránea de Prehistoria y Arqueología Social, 10, 7-20.

BELÉN DEAMOS, M., 2000: «Itinerarios arqueológicos por la geografía sagrada del lejano Occidente», en B. Costa y J.H. Fernández (eds.), Santuarios fenicio-púnicos en Iberia y su influencia en los cultos indígenas, XIV Jornadas de Arquelogía Fenicio-Púnica (Eivissa, 1999), Treballs del Museo Arqueològic d'Eivissa i Formentera 46, 57-102, Ibiza.

BERNAL CASASOLA, D., 2009: «El faro romano de Gades y el papel de los thynnoskopeia en el Fretum Gaditanum», Brigantium: Boletín do Museu Arqueolóxico e Histórico da Coruña, 20, 85-107.

BERNAL CASASOLA, D., 2012: «El puerto romano de Gades. Novedades arqueológicas», en S. Keay (ed.), Rome, Portus and the Mediterranean, Archaeological Monographs of the British School at Rome, 225-244, Londres.

BLANCO, M. C., 1970: «Nuevas piezas fenicias del Museo Arqueológico de Cádiz», AEspA, 43, 50-61.

BOTTO, M. (ed.), 2014: Los Fenicios en La Bahía de Cádiz. Nuevas investigaciones, Collezione di Studi Fenici 46, Pisa-Roma.

CARRETERO, P., 2007: Agricultura y Comercio PúnicoTurdetano en el Bajo Guadalquivir. El inicio de las explotaciones oleícolas peninsulares (siglos IV-II a.C.), BAR International Series 1703, Oxford.

CINTAS, P., 1950: Ceramique Punique, Publications de l'Institut des Hautes Etudes de Tunis III, Túnez.
CÓRDOBA, I. y RUIZ MATA, D., 2005: «El asentamiento fenicio arcaico de la calle Cánovas del Castillo (Cádiz). Un análisis preliminar», Congreso Internacional El Periodo Orientalizante, III Simposio de Arqueología de Mérida (Mérida, mayo de 2003), Anejos de AEspA XXXIII (2), 1269-1322, Mérida.

CORZO SÁNCHEZ, R., 1980: «Paleotopografía de la bahía gaditana», Gades, 5, 5-14.

CORZO SÁNCHEZ, R., 1983: «Cádiz y la arqueología fenicia», Anales de la Real Academia de Bellas Artes de Cádiz, 1, 5-29.

CORZO SÁNCHEZ, R., 1992: «El templo de Hércules gaditano en época romana», Boletín del Museo de Cádiz, $\mathrm{V}, 37-47$.

CORZO SÁNCHEZ, R., 1999: Venus Marina Gaditana, Fundación El Monte, Sevilla.

DE LA CONCEPCIÓN, Fr. G., 1690: Emporio de el Orbe, Cádiz Ilustrada. Investigaciones de sus antiguas grandezas, discurrida en Concurso de el General Imperio de España, Ámsterdam.

DOMÍNGUEZ-BELLA, S., 2008: «Geología en el entorno de la ciudad de Cádiz», Revista Atlántica-Mediterránea de Prehistoria y Arqueología Social, 10, 117-130.

FERRER ALBELDA, E. 2002: «La religión de época púnica en Iberia: lugares de culto», en E. Ferrer (ed.), Ex Oriente Lux. Las religiones orientales antiguas en la Península Ibérica, 185-218, Sevilla.

FROST, H., 2002: «Byblos: the lost temple, the cedars and the sea. A marine archaeological survey», Archaeology and History in the Lebanon, 14, 57-77.

GARCÍA Y BELLIDO, A., 1971: «Parerga de Arqueología y Epigrafía Hispano-romana. IV», AEspA, 44 (123-124), 137-152.

GENER BASALLOTE, J. M., JURADO FRESNADILLO, G., PAJUELO SÁEZ, J. M. y TORRES ORTIZ, M., 2014: «El proceso de sacralización del espacio en Gadir: el yacimiento de la Casa del Obispo (Cádiz). Parte I», en M. Botto (ed.), Los Fenicios en La Bahía de Cádiz. Nuevas investigaciones, Collezione di Studi Fenici 46, 123-155, Pisa-Roma.

GENER BASALLOTE, J. M., NAVARRO, M. A., PAJUELO, J. M., TORRES, M. y LÓPEZ, E., 2014: «Arquitectura y urbanismo de la Gadir fenicia: el yacimiento del Teatro Cómico de Cádiz», en M. Botto (ed.), Los Fenicios en La Bahía de Cádiz. Nuevas investigaciones, Collezione di Studi Fenici 46, 14-50, Pisa-Roma.

HIGUERAS-MILENA CASTELLANO, A. y SÁEZ ROMERO, A., 2014: «Aplicación experimental de técnicas geofísicas para la localización, investigación y difusión del patrimonio arqueológico en la zona de La Caleta (Cádiz)», en X. Nieto y M. Bethencourt (eds.), Arqueología Subacuatica Española, Actas del I Congreso de Arqueología Náutica y Subacuática Española (Cartagena, 14-16 de marzo de 2013), vol. II, 275-286, Cádiz.

HIGUERAS-MILENA CASTELLANO, A. y SÁEZ ROMERO, A., en prensa: «La circulación de productos envasados en ánforas en la Gades republicana: nuevos datos procedentes de contextos subacuáticos de La Caleta (Cádiz)», en Congreso Internacional «Cultura material 
romana en la Hispania Republicana. Contextos privilegiados y estado de la cuestión» (Lezuza, Albacete, 2224 de Abril de 2016).

GONZÁLEZ CESTEROS, H., HIGUERAS-MILENA, A. y SÁEZ ROMERO, A. M., en prensa: «Importaciones efesias en Cádiz: Nuevos hallazgos de la Punta del Nao (La Caleta)», Saguntum, 48.

GRACIA, J., GUTIÉRREZ MÁS, J.M., DOMÍNGUEZBELLA, S., ALONSO VILLALOBOS, C. y SÁNCHEZ BELLÓN, A., 2012: «Evolución de la Bahía de Cádiz en el transcurso de los tiempos geológicos», Celebración Geológica del Bicentenario de 1812, Geología 12, 1-20, Cádiz.

GUTIÉRREZ LÓPEZ, J. M., 2000: «Aportaciones a la producción de salazones de Gadir: la factoría púnicogaditana Puerto 19», Revista de Historia de El Puerto, 24, 11-46.

JIMÉNEZ FLORES, A. M., 2007: «Las imágenes en el servicio de culto: acerca del «supuesto» timiaterio de Punta del Nao», Habis, 38, 61-78.

KBIRI ALAOUI, M., 2007: Revisando Kuass (Asilah, Marruecos). Talleres cerámicos en un enclave fenicio, púnico y mauritano, Saguntum Extra-7, Valencia.

LÓPEZ DE LA ORDEN, M. D. y GARCÍA RIVERA, C., 1985: «Ánforas púnicas de la Caleta, Cádiz», en VI Congreso Internacional de Arqueología Submarina (Cartagena, 1982), 393-397, Cartagena.

MARÍN CEBALLOS, M. C., 2010: «Santuarios prerromanos de la costa atlántica andaluza», en T. Tortosa y S. Celestino (eds.), Debate en torno a la religiosidad protohistórica, Anejos de AespA LV, 219-244, Madrid.

MARÍN CEBALLOS, M. C. y JIMÉNEZ FLORES, A. M., 2011: «El capitel protoeólico de Cádiz», en M.C. Marín Ceballos (ed.), Cultos y ritos de la Gadir fenicia, 207220, Cádiz-Sevilla.

MARTÍ SOLANO, J., 2010: «Prospecciones y sondeos arqueológicos en el yacimiento subacuático de Bajos de Chapitel. Bahía de Cádiz», Anuario Arqueológico de Andalucía 2006, 628-643.

MARTÍ SOLANO, J. y RODRÍGUEZ, N., 2003: «Problemática y situación actual de la arqueología subacuática en la Bahía de Cádiz», Monte Buciero, 9, 397-416.

MARZOLI, D., 2000: «Ánforas púnicas de Morro de Mezquitilla (Málaga)», IV Congreso Internacional de Estudios Fenicios y Púnicos (Cádiz 1995), vol. IV, 1631-1644.

MAYA TORCELLY, R., JURADO, G., GENER, J. M., LÓPEZ, E., TORRES, M. y ZAMORA, J. A., 2014: «Nuevos datos sobre la posible ubicación del Kronion de Gadir: las evidencias de época fenicia arcaica», en M. Botto (ed.), Los Fenicios en La Bahía de Cádiz. Nuevas investigaciones, Collezione di Studi Fenici 46, 156-180, Pisa-Roma.

MUÑOZ VICENTE, A., 1992: «En tomo a seis askoi zoomorfos de la necrópolis púnica de Cádiz», Boletín del Museo de Cádiz, V, 7-15.

MUÑOZ VICENTE, A., 1993: «Las cerámicas feniciopúnicas de origen submarino del área de la Caleta (Cádiz)», Cuadernos de Prehistoria y Arqueología Castellonenses, 15 (1990-1991), 287-333.
MUÑOZ VICENTE, A., 2002: «El pasado fenicio-púnico», en Cádiz al fin del milenio. Cinco años de arqueología en la ciudad (1995-2000), Catálogo de la Exposición (Museo de Cádiz, enero-marzo 2002), 22-38, Sanlúcar de Barrameda.

NIVEAU DE VILLEDARY, A. M., 1999: «Ánforas turdetanas, mediterráneas y púnicas del s. III del Castillo de Doña Blanca (El Puerto de Santa María, Cádiz)», XXIV Congreso Nacional de Arqueología (Cartagena 1997), vol. 3, 133-140, Cartagena.

NIVEAU DE VILLEDARY, A. M., 2002: «Las ánforas turdetanas del tipo Pellicer-D. Ensayo de clasificación», Spal, 11, 233-252.

NIVEAU DE VILLEDARY, A. M., 2009: Ofrendas, banquetes y libaciones. El ritual funerario en la necrópolis púnica de Cádiz, Spal Monografías XII, Sevilla.

NIVEAU DE VILLEDARY, A. M., 2014: «La estructuración del espacio urbano y productivo de Gadir durante la fase urbana clásica. Cambios y perduraciones», Complutum, 26.1, 225-242.

NIVEAU DE VILLEDARY, A. M. y CÓRDOBA, I., 2003: «Algunas consideraciones sobre la religiosidad de Gadir. Nuevos datos para su estudio», Saguntum, 35, 123-145.

NÚÑEZ CALVO, F. J., 2013: «De Tiro a Almuñécar. Conexiones metropolitanas de un contexto colonial fenicio», Madrider Mitteilungen, 54, 27-87.

PEMÁN, C., 1959: «El capitel de tipo protojónico de Cádiz», AEspA, 32, 58-70.

PAJUELO SÁEZ, J. M., JURADO, G., MAYA, R. y LÓPEZ, J. M., en prensa: «Resultado de la actividad arqueológica preventiva en el solar $\mathrm{n}^{\circ}$ 49-51 de la calle San Rafael. Cádiz», Anuario Arqueológico de Andalucía, Sevilla.

PÉREZ HORMAECHE, E., 1990: «Arqueología Gaditana I: quemaperfumes púnicos», Gades, 19, 9-23.

PÉREZ HORMAECHE, E., 1993: «Arqueología Gaditana II: ungüentarios púnicos», Gades, 21, 261-268.

PÉREZ LÓPEZ, I., 1998: Los santuarios de la Baetica en la Antigüedad, Cádiz.

PONCE CORDONES, F., 1985: «Consideraciones en torno a la ubicación del Cádiz fenicio», Anales de la Universidad de Cádiz, II, 99-121.

RAMÍREZ DELGADO, J. R., 1982: Los primitivos núcleos de asentamiento en la ciudad de Cádiz, Cádiz.

RAMÍREZ DELGADO, J. R. y MATEOS ALONSO, V., 1985: «La arqueología subacuática en la bahía de Cádiz», en Actas del VI Congreso Internacional de Arqueología Submarina (Cartagena, 1982), 75-82, Cartagena.

RAMÍREZ DELGADO, J. R. y MATEOS ALONSO, V., 1992: «Terracota negroide de la Punta del Nao (Cádiz)», Boletín del Museo de Cádiz, 5, 31-36.

RAMÍREZ DELGADO, J. R. y MATEOS ALONSO, V., 1994: «Terracota orientalizante de la Punta del Nao (Cádiz)», Boletín del Museo de Cádiz, 6, 93-99.

RAMON TORRES, J., 1985: «Tagomago 1: un pecio fenicio del siglo V a.C. en aguas de Ibiza», VI Congreso Internacional de Arqueología Subacuática (Cartagena 1982), 377-391, Cartagena. 
RAMON TORRES, J., 1995: Las ánforas fenicio-púnicas del Mediterráneo Central y Occidental, Colección Instrumenta 2, Barcelona.

RAMON TORRES, J., 2004: «Las ánforas fenicio-púnicas de Ceuta», en D. Bernal (ed.), Juan Bravo y la arqueología subacuática en Ceuta, 95-106, Málaga.

RAMON, J., SÁEZ, A., SÁEZ ROMERO, A. M. y MUÑOZ, A., 2007: El taller alfarero tardoarcaico de Camposoto, Monografías de Arqueología 26, Sevilla.

RODRÍGUEZ, N. y MARTÍ, J., 2001: «Actuación arqueológica subacuática en los bajos al noroeste de la ciudad de Cádiz», Boletín del IAPH, 36, 75-82.

ROMERO DE TORRES, E., 1934: Catálogo Monumental de España. Provncia de Cádiz (1908-1909), Madrid.

RUIZ MATA, D. y PÉREZ, C. J., 1995a: «Aspectos funerarios en el mundo orientalizante y colonial de Andalucía occidental», en R. Fábregas, F. Pérez y C. Fernández (eds.), Arqueoloxía da Morte na Península Ibérica desde as Orixes ata o Medioevo, 169-221, Xinzo de Limia.

RUIZ MATA, D. y PÉREZ, C. J., 1995b: El poblado fenicio del Castillo de Doña Blanca (El Puerto de Santa María, Cádiz), El Puerto de Santa María.

SÁEZ ROMERO, A. M., 2006: «Uso y producción de askoi en Gadir. Una posible evidencia del culto a Tanit», Congreso Internacional L'Africa Romana XVI (Rabat, diciembre de 2004), 613-634, Roma.

SÁEZ ROMERO, A. M., 2008: La producción cerámica en Gadir en época tardopúnica (siglos-III/-I), BAR International Series, 1812 (2 vols.), Oxford.

SÁEZ ROMERO, A. M., 2009: «El templo de Melqart de Gadir: hito religioso-económico y marítimo. Consideraciones sobre su relación con la industria conservera», en P. Mateos, S. Celestino, A. Pizzo y T. Tortosa (eds.), Santuarios, oppida y ciudades: Arquitectura sacra en el origen y desarrollo urbano del Mediterráneo Occidental (Mérida, noviembre de 2005), Anejos de AEspA XLV, 115-130, Madrid.

SÁEZ ROMERO, A. M., 2010: «Comercio, procesado y consumo. Análisis evolutivo de algunas familias cerámicas gadiritas de época púnica y tardopúnica», en $\mathrm{C}$. Mata, G. Pérez y J. Vives-Ferrándiz (eds.), De la cuina a la taula. IV Reunió d'Economia en el Primer Mil-lenni a.C., Saguntum Extra 9, 303-312, Valencia.

SÁEZ ROMERO, A. M., 2014a: Alfares y saladeros de Gadir. Una aproximación arqueológica a la economía conservera de la Bahía de Cádiz en época púnica y tardopúnica (siglos -VI a-I), Tesis doctoral inédita, Universidad de Cádiz.

SÁEZ ROMERO, A., 2014b: «Ramon T-8211 (Costa de Baetica)». Amphorae ex Hispania. Paisajes de producción y consumo. Laboratorio Virtual < http:// amphorae.icac.cat/tipol/view/71> (consulta 20-4-2016).

SÁEZ ROMERO, A. M., en prensa: «Más allá de ánforas y salazones. Estructuras y dinámicas comerciales de $G a$ dir entre los siglos -VI y -III», Rivista di Studi Fenici.

SÁEZ ROMERO, A. M. y BELIZÓN, R., 2014: «Excavaciones en la calle Hércules, 12 de Cádiz. Avance de resultados y primeras propuestas acerca de la posible necrópolis fenicia insular de Gadir», en M. Botto (ed.), Los Fenicios en La Bahía de Cádiz. Nuevas investigaciones, Collezione di Studi Fenici 46, 181-201, Pisa-Roma.

SÁEZ ROMERO, A. M. e HIGUERAS-MILENA CASTELLANO, A., en prensa: «Cerámicas fenicias arcaicas de procedencia subacuática del área de La Caleta (Cádiz): ensayo de contextualización e interpretación histórica», Cuadernos de Prehistoria y Arqueología de la Universidad Autónoma de Madrid, 42.

SÁEZ ROMERO, A. M., GONZÁLEZ, H. e HIGUERASMILENA, A., 2016a: «Una aportación al estudio del comercio marítimo antiguo gaditano a partir de un conjunto de ánforas halladas en aguas del área de La Caleta (Cádiz)», Onoba: Revista de Arqueología y Antigüedad, 4, 3-18.

SÁEZ ROMERO, A. M., LUACES, M. y MORENO, E., en prensa: «Late Punic or Early Roman? A 2nd Century BC deposit from Gadir/Gades (Cadiz Bay, Spain)», HEROM - Journal on Hellenistic and Roman Material Culture, 5.1, 25-75.

SÁEZ ROMERO, A. M. y NIVEAU, A., 2014: «Pellicer D (Costa de Ulterior/Baetica)», Amphorae ex Hispania. Laboratorio online: Tipologías anfóricas <http://amphorae.icac.cat/tipol/view/70> (consulta 20-04-2016).

SCHUBART, H. y NIEMEYER, H.G., 1976: Trayamar: los hipogeos fenicios y el asentamiento en la desembocadura del rio Algarrobo, Excavaciones Arqueológicas en España 90, Madrid.

ZIMMERMAN-MUNN, M. L., 2003: «Corinthian trade with the punic west in the Classical period», en C. K. Williams II y N. Bookidis (eds.), Corinth. The Centenary 1896-1996, Corinth XX, 195-217.

VALLESPÍN GÓMEZ, O., 1977: «Prospecciones submarinas en Cádiz. Agosto 1973», Noticiario Arqueológico Hispánico, Arqueología, 5, 289-292, Madrid.

VALLESPÍN GÓMEZ, O., 1985: «Carta Arqueológica de La Caleta», en Actas del VI Congreso Internacional de Arqueología Submarina (Cartagena, 1982), 59-74, Cartagena.

VERA, F. y VERA, J. A., 1887: Antigüedades de la isla de Cádiz, Tipografía de J. Benítez Estudillo, Cádiz. 